Article

\title{
Influence of Treatment Time on Performance of Cr(III)-Based Conversion Coatings on Hot Dip Zn-55Al-1.6Si Coated Steel Sheet
}

\author{
Jie Pan, Xiao Tang and Yan $\mathrm{Li}$ *[D
}

School of Material Science and Engineering, China University of Petroleum (East China), Qingdao 266580, China; b16040143@s.upc.edu.cn (J.P.); tangxiao@upc.edu.cn (X.T.)

* Correspondence: yanlee@upc.edu.cn; Tel.: +86-1361-532-1199

Received: 29 March 2019; Accepted: 24 April 2019; Published: 1 May 2019

check for updates

\begin{abstract}
In this work, the effect of treatment time on the performance of $\mathrm{Cr}(\mathrm{III})$ conversion coatings (TCC) on hot dip Zn-55Al-1.6Si (Zn55Al) coated steel sheet were investigated. The surface 3D morphology and roughness of TCCs were examined by a 3D topography instrument and the structure, chemical composition, and elemental depth distribution were studied by means of scanning electron microscope (SEM), X-ray photoelectron spectroscopy (XPS), and auger electron spectroscopy (AES). The results indicated that during the formation of TCC, the macro-roughness of Zn55Al surface was reduced, but the micro-roughness increased, which are considered to be key factors in enhancing the adhesion strength of epoxy primers. The AES depth profiles showed a two-layer TCC for both dendritic and inter-dendritic regions and chemical composition analysis of XPS showed that the surface of TCC was mainly oxides, fluoride and a small number of hydroxides. Overall, Zn55Al specimen prepared in a diluted commercial $\mathrm{Cr}$ (III)-based solution for $180 \mathrm{~s}$ at $40{ }^{\circ} \mathrm{C}$ performed a better adhesion strength to epoxy primer and had the largest polarization resistance among all TCCs in this work. Additionally, longer $\mathrm{Cr}$ (III) passivation process (TCP) treatment time will increase the sensitivity of the TCC to micro-cracks.
\end{abstract}

Keywords: hot dip Zn55Al coated steel; trivalent chromium conversion coating (TCC); trivalent chromium passivation process (TCP); physicochemical properties; adhesion strength; corrosion resistance

\section{Introduction}

Hot dip coated steel (Zn-55Al-1.6Si, hereinafter referred to as Zn55Al) is widely used in residential or factory decoration, parts of electrical appliances or automobiles, engineering construction, and other fields. The uniform and fine, glittery appearance of the $\mathrm{Zn} 55 \mathrm{Al}$ provides an aesthetic benefit in buildings constructed from unpainted products, and the unique composition and microstructure of this coating combines the good durability of aluminum coating with the sacrificial characteristics of zinc coating [1-6]. During the last decades, the process for obtaining hot-dip coated steel is transformed to a modern technology that requires additional surface treatment; for example, short-time immersion in specially developed chemical solutions for obtaining conversion coatings (CCs). In addition, as the bottom design of the coating system, both the improvement of corrosion resistance and adhesion strength to subsequent primers are the main points that people will pay attention to in the future.

Epoxy coating has been widely used on the steel substrates in order to protect them against corrosive environments, which plays out as a physical barrier between the metal surface and corrosive environment $[7,8]$. However, when exposed to electrolytes containing oxygen, water, and ions for a long time, the penetration of these components into the primer lead to a decrease in the adhesion of the coating. One potential advantage of chemical conversion coatings is that they can improve 
the adhesion of subsequent organic or epoxy primers [9]. Sababi et al. proved that the Zr-based treatment can significantly improve dry adhesion and, moreover, wet durability of fusion bonded epoxy to carbon steel upon exposure to a sodium chloride electrolyte, by inhibiting the formation of large water aggregates and preventing epoxy disbonding at the interface [10]. Ramezanzadeh et al. reported an enhanced anticorrosion performance as well as the promoted adhesion properties of the epoxy nano-composite (containing nano- $\mathrm{ZnO}$ particles) on the surface of hot dip galvanized specimens pre-treated by $\mathrm{Cr}(\mathrm{III})$ and $\mathrm{Cr}(\mathrm{VI}) \mathrm{CCs}$ [11]. Asemani et al. and Hosseini et al. revealed that the carbon mild steel surface treated by hexafluorozirconic acid based conversion coating had better performance in a salt spray test and electrochemical measurements against corrosive media [12,13]. Golru et al. also proved that the Zr-based conversion layer improved adhesion of the epoxy paint on the AA1050 [14,15]. Ghanbari et al. indicated that the formation of oxide-hydroxide of zirconium and adsorbed fluoride ion on the mild steel should be responsible to the increment of adhesion of the organic coating to the steel surface treated by a zirconium-based conversion layer [16].

Certainly, the trivalent chromium passivation process (TCP) will be the focused research in this field due to the environmental injunction and global emphasis on eliminating hexavalent chromium [17]. To search for an effective alternative to $\mathrm{Cr}(\mathrm{VI})$-based chemical conversion coatings, much research has been done on the $\mathrm{Cr}$ (III) based or Zirconium-based conversion coating on zinc alloy coatings [18-21] and aluminum alloys such as AA1050 [14,15]; AA2024 [22-26], AA5052 [27], AA6014 [28,29], AA6063 [30], AA7075 [31-34] surfaces, etc. Comparisons were also made on zinc and various aluminum alloys on concerned performances $[28,34,35]$. Unlike these alloys, the zinc-rich inter-dendritic and aluminum-rich dendritic regions of $\mathrm{Zn} 55 \mathrm{Al}$ interlace with each other, and there are no isolated secondary phase intermetallic particles on its surface. Due to the special surface condition of Zn55Al hot-dip coating (containing Zn-rich inter-dendritic region and Al-rich dendrite region), the formation process of trivalent chromium chemical conversion coating on its surface is different from that of zinc alloys or aluminum alloys $[4,6,36]$.

The complexity of the microstructure and the chemical composition of the industrial Zn55Al make a complete understanding of the TCP difficult. A low concentration chromate passivation treatment has been successfully processed on $\mathrm{Zn} 25 \mathrm{Al}$ by previous research, but it was $\mathrm{Cr}(\mathrm{VI})$ based [37]. The aim of this work was to characterize the $\mathrm{Cr}$ (III) based conversion coatings formed on Zn55Al, and to understand the influence of different TCP treatment time on TCC's performance. High sensitive surface techniques such as X-ray photoelectron spectroscopy (XPS) and auger electron spectroscopy (AES) were used for the surface and in-depth chemical characterization, and combined with SEM and 3D profiler for studies of the change of the TCC's morphology and roughness. In addition, the corrosion resistance of the $\mathrm{Zn} 55 \mathrm{Al}$ surfaces with different TCP treatment times was estimated by electrochemical measurements.

\section{Materials and Methods}

\subsection{Specimen Preparation and $\mathrm{Cr}(I I I)$ Treatment Process}

Commercial hot-dip Zn55Al coated steel sheet (55\%Al-43.4\%Zn-1.6\%Si by weight) with an average thickness of $25 \mu \mathrm{m} \mathrm{Al-Zn} \mathrm{coating} \mathrm{was} \mathrm{selected} \mathrm{as} \mathrm{the} \mathrm{subject.} \mathrm{The} \mathrm{spangled} \mathrm{microstructure} \mathrm{of}$ $\mathrm{Zn} 55 \mathrm{Al}$ consists of Al-rich dendritic regions (64.5\%Al-35.3\%Zn-0.2\%Si) and inter-dendritic $\mathrm{Zn}$-rich regions (20.4\%Al-78.9\% $\mathrm{Zn}-0.7 \% \mathrm{Si})$ [4].

The Cr(III) based passivator Bonderite M-NT 5928 (also known as Adoline 5928, Hankel Corp., Dusseldorf, Germany) containing 1-10 wt. \% trivalent chromium salt and 0.1-1 wt. \% zirconium compounds were prepared using ultrapure water (Ulupure Water Purification System, Ultrapure Technology Co., Ltd., Chengdu, China, $2.93 \mathrm{M} \Omega \cdot \mathrm{cm}$ ) to 50 vol. \%. The $\mathrm{pH}$ of the diluted solution is 2.6, detected by Quanta (Hydrolab Corp., Austin, TX, USA). The Cr(III) conversion process (hereinafter referred to as TCP) was carried out in a plastic beaker at $40{ }^{\circ} \mathrm{C}$ at different immersion time $(30,60,180$ and $360 \mathrm{~s}$ ) in order to investigate the properties of the trivalent chromium conversion coating (referred 
to as TCC for short). Afterwards, the Cr(III)-treated panels were dried in a lab dryer for at least $24 \mathrm{~h}$ at ambient temperature.

Prior to immersion in the $\mathrm{Cr}(\mathrm{III})$ bath, all the Zn55Al panels with a dimension of $50 \mathrm{~mm} \times 50 \mathrm{~mm}$ used in this research was edge-sealed and pre-treated with the same following processes: (i) ultrasonic cleaning in acetone for $10 \mathrm{~min}$; (ii) alkali washing for $15 \mathrm{~s}$ in $5 \mathrm{wt}$. \% NaOH solution at $50{ }^{\circ} \mathrm{C}$; (iii) acid pickling for $10 \mathrm{~s}$ in $10 \mathrm{wt}$. $\% \mathrm{HNO}_{3}$ solution which is usually used as desmutting bath at room temperature. Each process was followed by ultrasonic cleaning in ultrapure deionized water for $5 \mathrm{~min}$, then dried in a cool air stream. The purpose of the pre-treatment was to eliminate the fingerprint resistant coating on $\mathrm{Zn} 55 \mathrm{Al}$ and to activate the surface subjected to $\mathrm{Cr}(\mathrm{III})$-treatment. In order to perform 3D morphology analysis, half of a specimen was covered with insulating and corrosion-resistant tapes to retain the original surface in order to compare the surface morphology of TCP treated and untreated regions.

\subsection{Surface Composition Analysis}

A panel of $10.0 \mathrm{~mm} \times 10.0 \mathrm{~mm}$ previously subjected to TCP treatment of $180 \mathrm{~s}$ was used for the AES analysis and a typical area with inter-dendritic and dendritic region was selected. The AES measurements were performed on a PHI 710 scanning auger nanoprobe (ULVAC-PHI, Inc., Kanagawa, Japan) with a tungsten filament electron emission source. A cylindrical mirror analyzer (CMA) was adopted and the test beam energy used for stimulating specimen signals and SEM imaging is $10 \mathrm{kV}$, and the current is $10 \mathrm{nA}$. All the Auger electron spectra were acquired with an energy analyzer resolution less than $0.5 \%$. The surface was sputtered using a $2.0 \mathrm{keV} \mathrm{Ar}^{+}$ion beam over an area of $2.0 \mathrm{~mm} \times 2.0 \mathrm{~mm}$ and the emission current was $3.0 \mathrm{~mA} / \mathrm{cm}^{2}$. The mode of ion beam sputtering is spin sputtering, and the rotational speed is $1.0 \mathrm{rpm}$. The sputtering rate is based on $\mathrm{SiO}_{2}$ standard specimen, about $10 \mathrm{~nm}$ per minute. The incident angle of electron beam was 30 degrees, while the incidence angle of ion beam was 50 degrees. The recorded spectra were analyzed with Multipak V9.0 software. The characteristic peak of element $\mathrm{C}(275.0 \mathrm{eV})$ was used for calibration.

The chemical states of coating species treated by TCP for $180 \mathrm{~s}$ were determined by X-ray photoelectron spectroscopy (XPS), using an ESCALAB 250Xi system (Thermo Fisher Scientific Inc., Waltham, MA, USA) equipped with an $\mathrm{Al} / \mathrm{K}$ Alpha source. The micro focus monochromator was operated at a spot size of $500 \mu \mathrm{m}$, including the dendrite and inter-dendritic regions. In order to mitigate the influence of air pollutants and excess carbon on the test results, the $\mathrm{Ar}^{+}$ion sputtering depth was $5 \mathrm{~nm}$ and the high-resolution intensities of the $\mathrm{Cr} 2 p, \mathrm{Zr} 3 d, \mathrm{O} 1 s, \mathrm{Al} 2 p, \mathrm{Zn} 2 p$, etc. photoelectron lines were recorded separately. The background intensity was subtracted from the spectra using the Shirley method. All data were corrected by a linear shift such that the peak maximum of the $\mathrm{C} 1 \mathrm{~s}$ binding energy of adventitious carbon corresponded to $284.6 \mathrm{eV}$.

\subsection{Surface Micromorphology and Roughness Analysis}

A JSM-7200F microscope (JEOL Ltd., Tokyo, Japan) associated with an integral energy dispersive spectrometer (EDS) detector and operated at an accelerating voltage of $15 \mathrm{kV}$, were used to investigate surface morphologies and element distribution.

Zeta-20A 3D profiler instrument (Zeta Instruments, Milpitas, CA, USA) was used to observe the 3D morphology and to compare the surface roughness of TCCs with different immersion time. The field of view was $1164 \mu \mathrm{m} \times 873 \mu \mathrm{m}$. Surface profiles were obtained, repeatedly scanning a line extending from the untreated regions over the TCP-treated regions using a $10 \times$ objective lens with a length of $150 \mu \mathrm{m}$. The roughness $R_{a}$ was calculated by Zeta3D software (version 1.7.5), which is the arithmetic mean of the absolute ordinate values $Z(x)$ within a sampling length according to the ISO 12085 [38]:

$$
R_{a}=\frac{1}{l} \int_{0}^{l}|Z(x)| \mathrm{d} x
$$


$Z(x)$ refers to the height difference between the neighboring largest profile valley and largest profile peak. The average value of five measurements is taken as a result.

\subsection{Pull-off Adhesion Tests}

To study the effects of surface roughness and texture on the adhesion of the epoxy coating, epoxy zinc yellow primer-green was prepared on $\mathrm{Zn} 55 \mathrm{Al}$ with an epoxy resin and a hardener (volume ratio is $\sim 3: 1$ ) both from CSIC Corp. (Xiamen, China). The adhesive strength was characterized by a pull-off adhesion tester (PosiTest AT-A, DeFelsko Corp., New York, NY, USA) following a direct pull-off standardized procedure according to ASTM D4541 [39]. The dolly size was $\sim 20 \mathrm{~mm}$ and the pull rate was controlled at a speed of $0.2 \mathrm{MPa} / \mathrm{s}$. Specimens were kept at ambient temperature for at least $24 \mathrm{~h}$ (RT $\sim 22$ to $24^{\circ} \mathrm{C}$ ) to ensure that the glue fully cured before the test and a slot was made around dollies. All tests were carried out using three replicates to ensure the measurements' repeatability.

\subsection{Electrochemical Mesurements}

For the electrochemical measurements, a three-electrode cell was used with an Autolab PGSTAT $302 \mathrm{~N}$ potentiostat system (Metrohm AZ, Herisau, Switzerland). The cell contained an $\mathrm{Ag} / \mathrm{AgCl} / \mathrm{Cl}^{-}$ (saturated $\mathrm{KCl}$ ) electrode, a $3 \mathrm{~cm}^{2}$ platinum mesh counter electrode and a working electrode with an exposed area of $0.5 \mathrm{~cm}^{2}$. In order to acquire the polarization resistance of TCC for different conversion times, the linear polarization curves were carried out from -0.015 to $0.015 \mathrm{~V}$ vs. the OCP, with a scanning rate of $0.166 \mathrm{mV} / \mathrm{s}$. Measurements were carried out in a naturally aerated $0.5 \mathrm{M} \mathrm{NaCl}$ solution at room temperature. Besides, the cathodic polarization curves were obtained by scanning the potential from OCP to $0.150 \mathrm{~V}$ vs. the OCP in naturally aerated or nitrogen deoxidizing $0.05 \mathrm{M} \mathrm{NaCl}$ solution at room temperature, with a scanning rate of $1.0 \mathrm{mV} / \mathrm{s}$. In the electrolytic cell, Luggin capillary was used to compensate for IR drop. Nova software (version 2.1.3) was used to fit the experimental data.

\subsection{Contact Angle Mesurements}

The contact angle of pure water on the trivalent chromium conversion coatings was measured by a contact angle goniometer (XG-CAMC, Shanghai Xuanzhun Instrument Co., Shanghai, China) at room temperature to investigate the surface hydrophilicity. The hot-dip $\mathrm{Zn} 55 \mathrm{Al}$ steel samples were carefully cleaned to avoid surface contamination.

\section{Results}

\subsection{Roughness and 3D Morphologies Analysis}

The effect of TCP conversion treatment on the surface morphology of Zn55Al was visually obtained by 3D profiler, and the greyscale image as well as the color map clearly show the macro roughness difference between the TCP treated region and untreated region within one specimen. The 3D surface topography comparison of $\mathrm{Zn} 55 \mathrm{Al}$ specimens with different immersion time of 60,180 and $360 \mathrm{~s}$ in TCP bath at $40{ }^{\circ} \mathrm{C}$ is shown in Figure 1. Compared to the untreated Zn55Al surface, the 3D topography images reveal a strong attack and smoothing effect of TCP treatment on the treated Zn55Al surface. The TCP treatment diminished the height difference between peak and valley on the treated surface, making the TCP-treated surface macroscopically smoother. The morphology in Figure 1 reveals a relatively smoother surface after TCP treatment time of 180 and $360 \mathrm{~s}$ compared to $30 \mathrm{~s}$. Surface contour profiles were obtained by optical scanning at the same time, and Figure 2 reflects the profiles comparison of different specimens. Compared with an untreated specimen surface, the surface roughness of specimens decreased with the prolongation of immersion time, and since the beginning of TCC formation ( $60 \mathrm{~s}$ ), this effect had become obvious. 

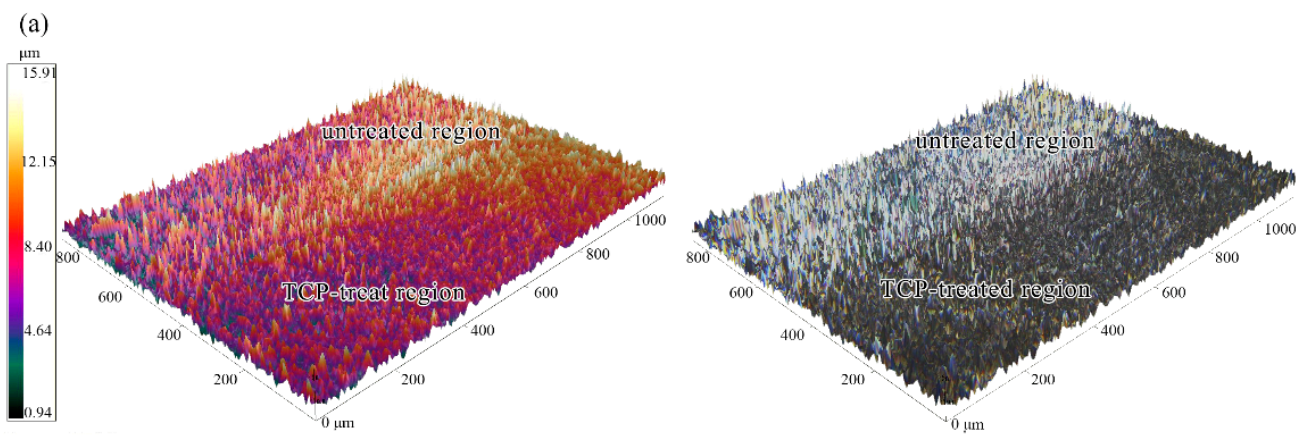

(b)
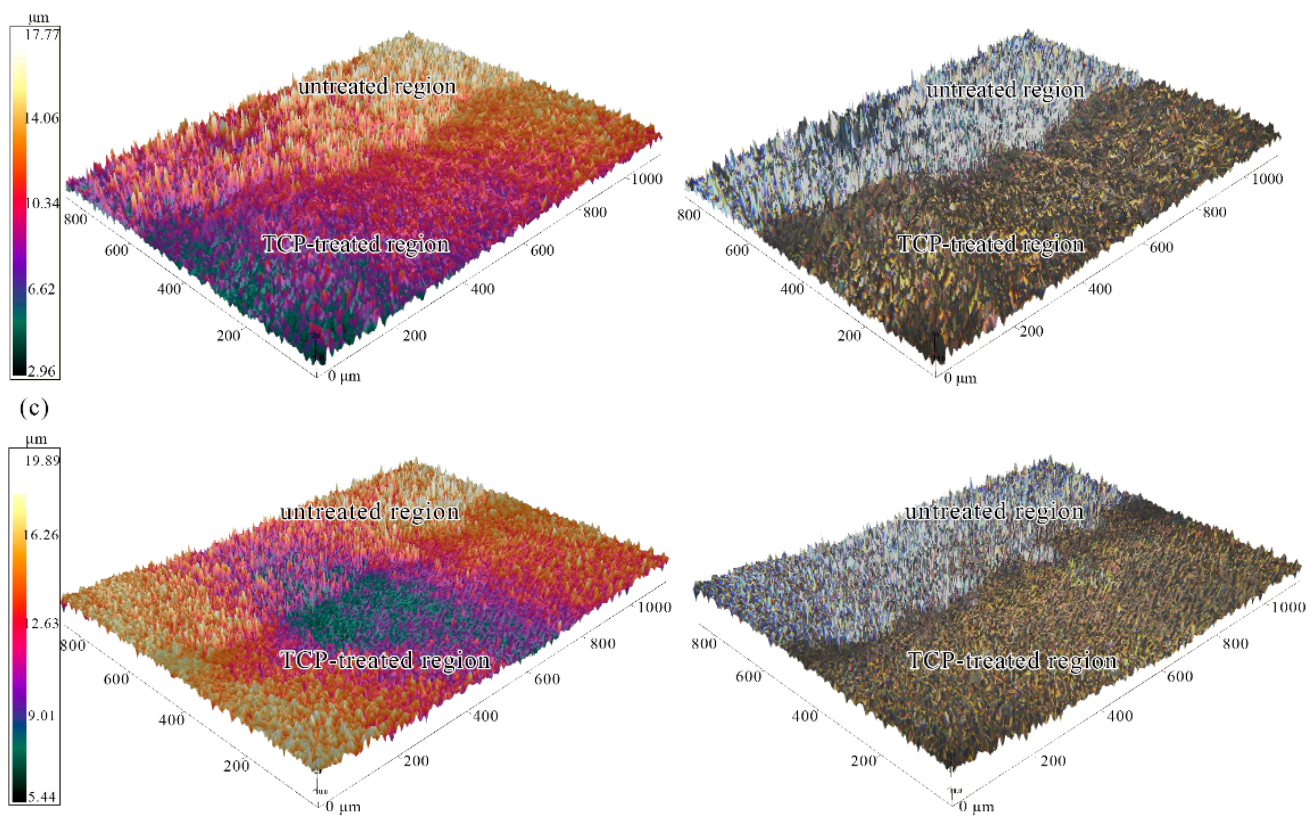

Figure 1. Surface 3D topography comparison of untreated and TCP-treated regions within one Zn55Al specimen surface with different immersion periods: (a) $30 \mathrm{~s}$; (b) $180 \mathrm{~s}$; (c) $360 \mathrm{~s}$ at $40{ }^{\circ} \mathrm{C}$ in the TCP bath.

Figure 3 reveals the surface roughness difference, which shows that the surface roughness of the region treated by TCP for $180 \mathrm{~s}$ was $57.19 \%$ lower than that of the surface without any treatment. However, the roughness reduction of the surface treated for $360 \mathrm{~s}$ did not increase further. After $360 \mathrm{~s}$ of TCP treatment, the surface roughness was reduced by $52.65 \%$, which is less than that of $180 \mathrm{~s}$ of TCP treatment. It is worth noting that pre-treatment also has the function of etching and modifying the surface, which plays an important role before TCP treatment [40]. Figure 3 also revealed the surface roughness change of $\mathrm{Zn} 55 \mathrm{Al}$ specimens which were processed only by the TCP treatment directly after ultrasonic cleaning with acetone. It can be concluded from Figure 3 that pre-treatment did promote the reduction of surface roughness of Zn55Al surface after TCP treatment, but the degree of the promotion was limited. The reduction of roughness should be attributed mainly to the process of the chemical conversion. 

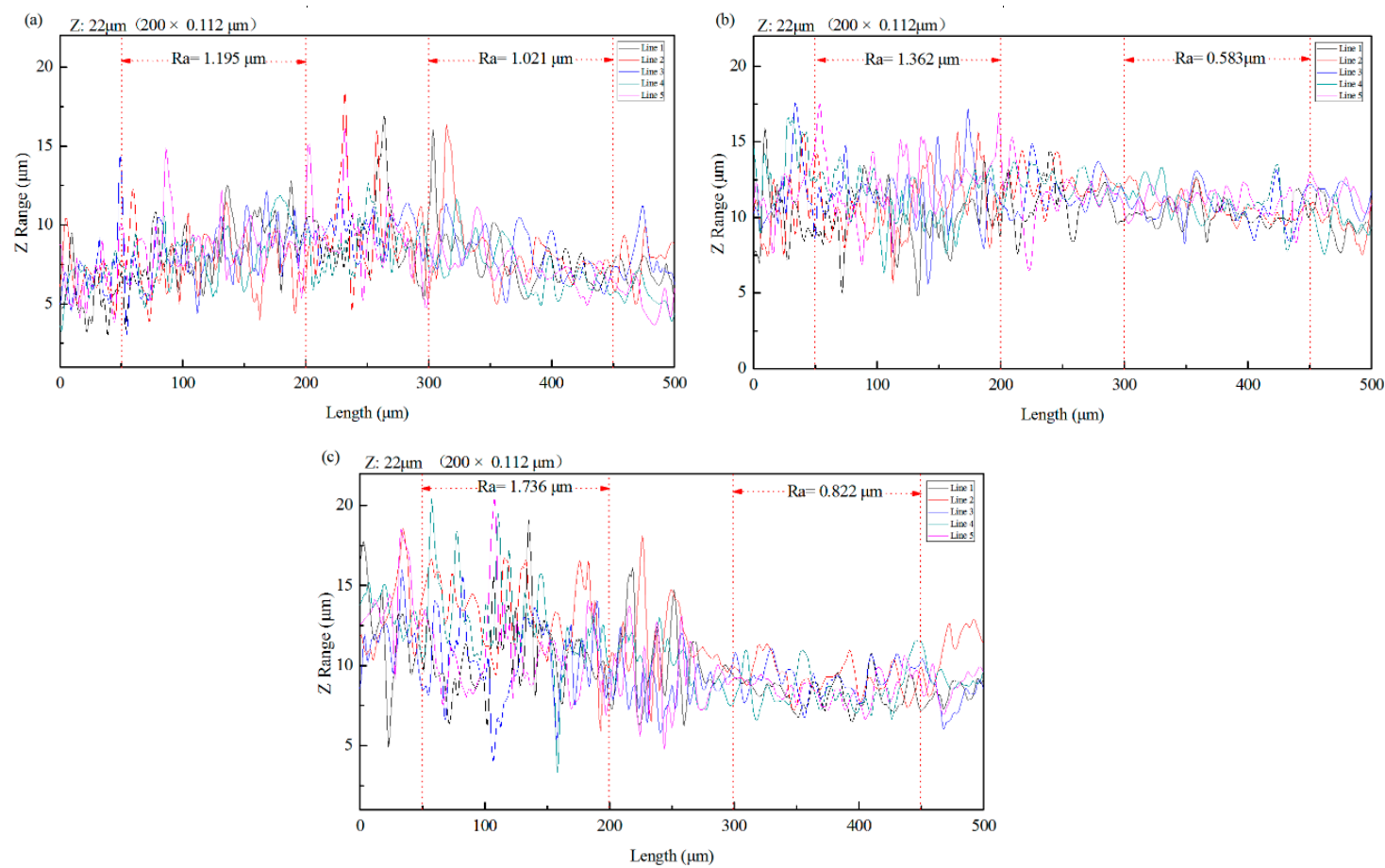

Figure 2. Surface profiles scanned from untreated region to TCP treated region, with average roughness $\left(R_{a}\right)$ calculated respectively. The TCP treatment conditions are: (a) $30 \mathrm{~s}$; (b) $180 \mathrm{~s}$; (c) $360 \mathrm{~s}$ at $40{ }^{\circ} \mathrm{C}$ in the TCP bath.

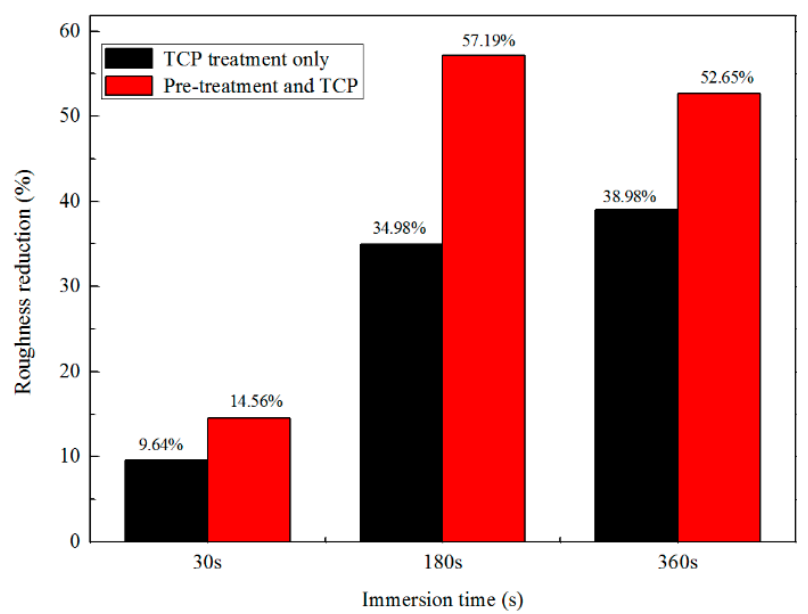

Figure 3. Roughness reduction of $\mathrm{Zn} 55 \mathrm{Al}$ surface with two kind of treatment at different immersion periods in the TCP bath.

\subsection{Surface Morphology Characterization}

Figure 4 presents a comparison SEM micrograph of a bare and pre-treated Zn55Al surface. For untreated $\mathrm{Zn} 55 \mathrm{Al}$, the surface regularly distributes bulging dendritic regions and depressing inter-dendritic regions. Dendrites on the surface of $\mathrm{Zn} 55 \mathrm{Al}$ are the aluminum-rich phase skeleton formed by undercooling during the hot-dipping process, and zinc-rich inter-dendritic regions are distributed in dendritic regions [4]. According to previous research, the inter-dendritic region properly distributed with spherical Al-rich particles, as shown in Figure 4a [4,36]. However, after pretreatment, the aluminum-rich spherical particles in the inter-dendritic region were dissolved, leaving a zinc-rich skeleton as shown in Figure $4 \mathrm{~b}$. Overall, pretreatment with pickling and alkali washing provided a microcosmically rougher surface for Zn55Al than untreated specimens. According to previous research, 
pretreatment plays an important role in removing the oxide layer on the surface and activating the surface of $\mathrm{Zn} 55 \mathrm{Al}$, which is beneficial to the formation of TCC [25,41,42].
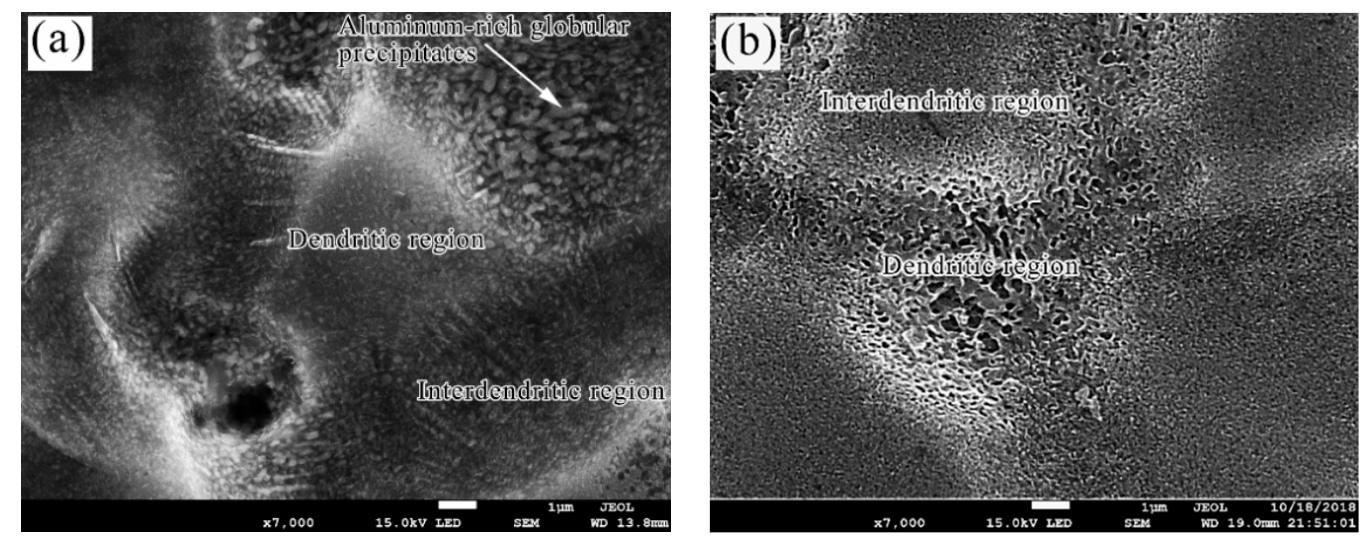

Figure 4. SEM micrograph of (a) bare Zn55Al surface and (b) Zn55Al surface pre-treated by pickling and alkali washing.

Figure 5 shows plan-view SEM images of the surface prepared in the TCP bath for 0, 30, 180 and $360 \mathrm{~s}$ at $40{ }^{\circ} \mathrm{C}$, respectively. The change of surface state shown in Figure 5 indicates that TCC does not form in the dendrite and inter-dendrite region at the same time, i.e., preferential film formation at dendrite. Figure $5 \mathrm{~b}$ shows that dendrites are covered by the formed $\mathrm{Cr}$ (III) conversion coating immediately at the initial stage of film formation, i.e., 30 s. Parts of dendritic regions were strongly etched and continuously covered with lamellar $\mathrm{Cr}$ (III) conversion films. The immersion time of 0-30 s was shown to be the beginning of coating growth [30]. During the subsequent film-forming process, the dendritic and inter-dendritic regions became almost as rough after $180 \mathrm{~s}$ of TCC formation, as shown in Figure $5 \mathrm{c}$, i.e., the contrast between concave and convex became weaker. Figure $5 \mathrm{c}$ also shows that after $180 \mathrm{~s}$ of TCP treatment, dendritic regions appeared dense micro-cracks in the vacuum environment, indicating a certain thicker TCC. A more cracked surface morphology after $360 \mathrm{~s}$ of film formation is shown in Figure $5 \mathrm{~d}$. The length of micro-cracks in the transition zone between inter-dendritic and dendritic regions is $\sim 5 \mu \mathrm{m}$, which indicates a porous, thick film in this area.

Figure 6 revealed some fine micro-cracks in the dendritic region on Zn55Al by TCP-treated $180 \mathrm{~s}$. The length of micro-cracks is less than $\sim 2 \mu \mathrm{m}$, which is slightly shorter than the length of transition part between the dendrite region and dendrite inter-dendrite region. Microscopically, the conversion film at dendrite is composed of many nano-spherical particles with a diameter of $\sim 100 \mathrm{~nm}$ [43]. Of course, this kind of high degree of micro-roughness, which is the most important feature of a conversion coating, could benefit the adhesion of the primers to the substrate surface.

According to previous research, micro-cracks are obviously caused by dehydration of the conversion coating, which is undoubtedly aggravated by a vacuum drying environment during SEM observations [24,27]. 

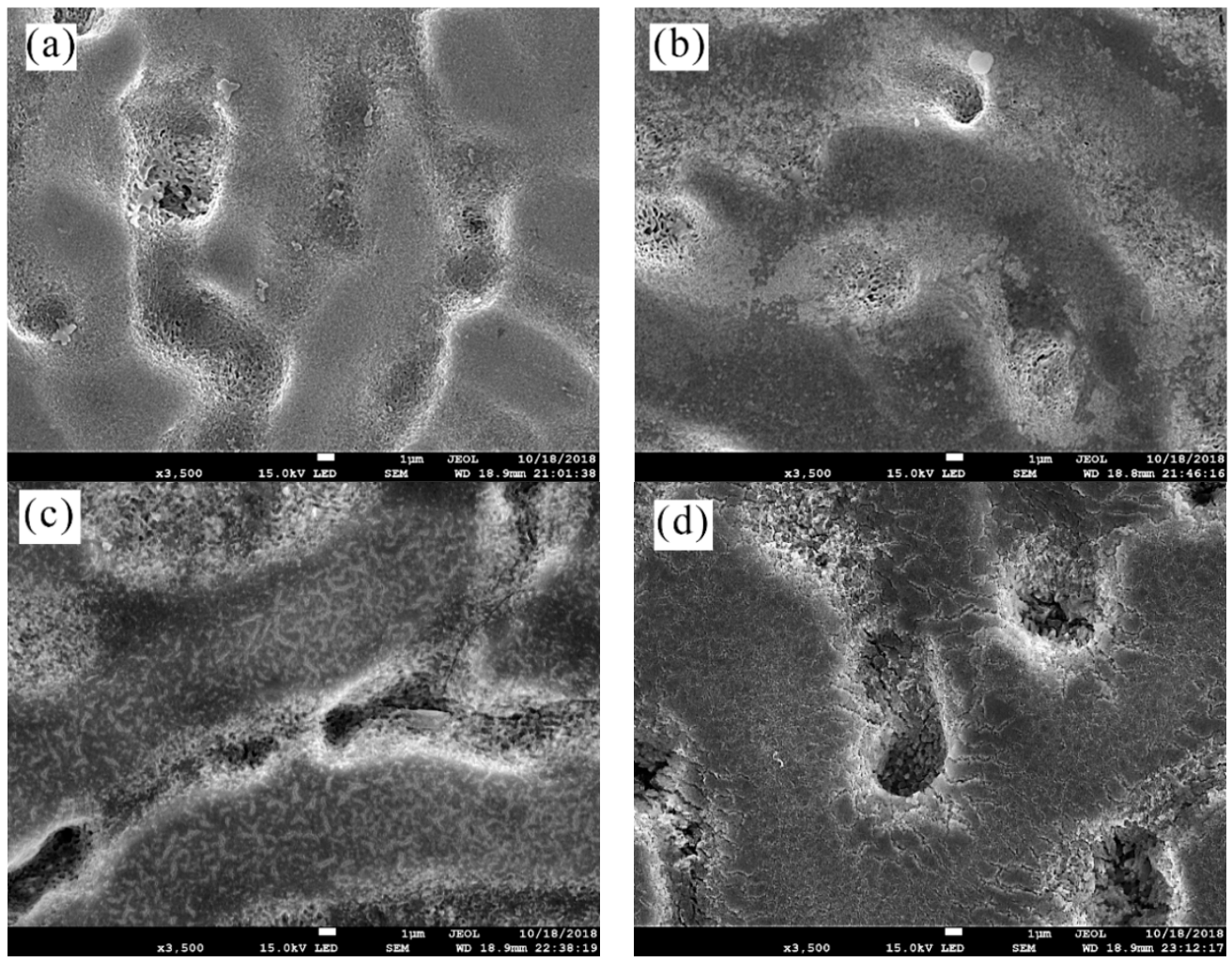

Figure 5. Plan-view SEM micrographs of TCC prepared in the TCP bath at $40{ }^{\circ} \mathrm{C}$ with (a) $0 \mathrm{~s}$; (b) $30 \mathrm{~s}$; (c) $180 \mathrm{~s} ;$ (d) $360 \mathrm{~s}$.
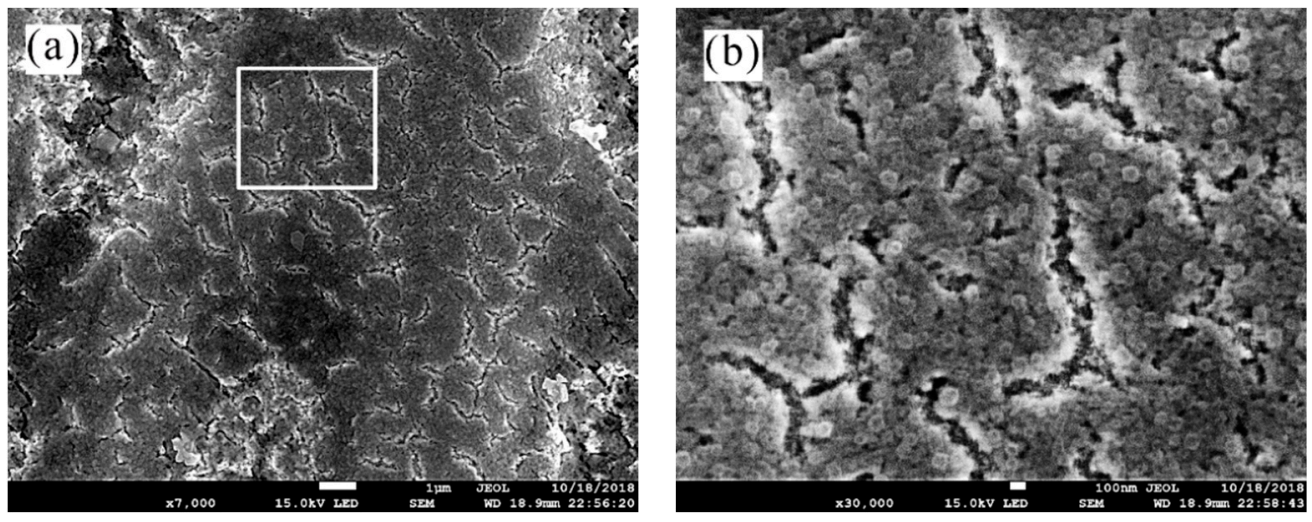

Figure 6. SEM micrograph of a TCC on $\mathrm{Zn} 55 \mathrm{Al}$ formed by $180 \mathrm{~s}$ at $40{ }^{\circ} \mathrm{C}$ in $\mathrm{TCP}$ bath with different magnification: (a) 7000×; and (b) 30,000×.

\subsection{Pull-off Adhesion Measurements}

In this work, dry adhesion of epoxy primer on untreated and TCP treated Zn55Al specimens was measured by the standard pull-off methods. Results obtained from a pull-off test, and also the photographs of the specimens after this test, are presented in Figure 7 with the bonding strengths at approximately 1.54 and $1.05 \mathrm{MPa}$ for TCP treated and bare $\mathrm{Zn} 55 \mathrm{Al}$, respectively. From Figure 7 it can be clearly seen that the adhesion strength of TCP treated specimens with epoxy primer increased by $47.61 \%$. The test area of the bare $\mathrm{Zn} 55 \mathrm{Al}$ coated by the epoxy primer exhibits nearly $80 \%$ detachment at the interface with the substrate, while more epoxy primer adhered to the surface of the TCP treated specimen. It is evident that the improvement of the adhesion bonds between epoxy primer/substrates after formation of conversion coating leads to debonding from the internal layer of the epoxy primer $[14,15]$. 


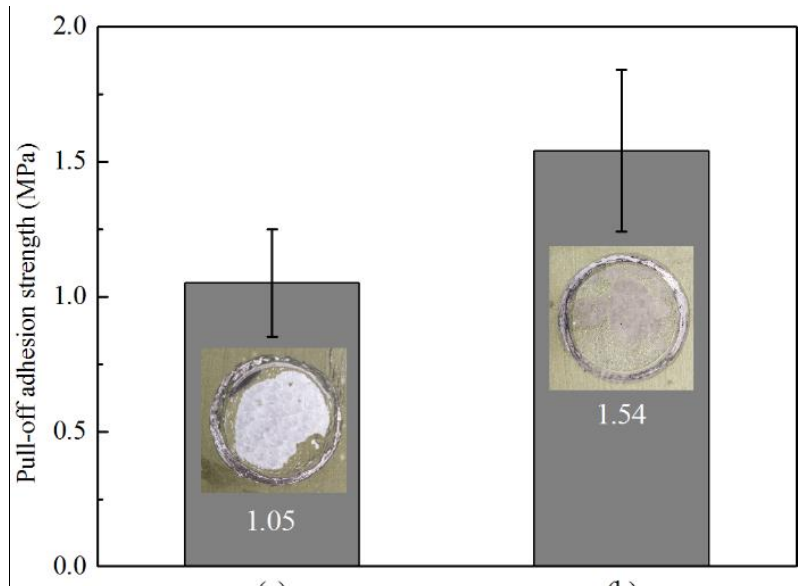

(a)

(b)

Figure 7. Pull-off adhesion strength measurements of the epoxy coatings applied on (a) degreased Zn55Al specimens; (b) Zn55Al specimens treated by $180 \mathrm{~s}$ at $40{ }^{\circ} \mathrm{C}$.

\subsection{Electrochemical Characterization}

The polarization curves performed from -0.015 to $0.015 \mathrm{~V}$ vs. OCP in $0.5 \mathrm{M} \mathrm{NaCl}$ solutions of $\mathrm{Zn} 55 \mathrm{Al}$ treated by TCP for 30, 60, 120,180, and $360 \mathrm{~s}$ are depicted in Figure 8. Within the range of $20 \mathrm{mV}$ near the corrosion potential $E_{c o r r}$, the relationship between polarization current $i$ and polarization potential $E$ is linear. The polarization resistance $R_{p}$ which is an important thermodynamic parameter of corrosion electrochemistry, can be obtained by the slope of linear zone near the free-corrosion potential $E_{\text {corr }}$. According to Butler-Volmer polarization curve equation, the relationship between $R_{p}$ value and $i_{\text {corr }}$ is as follows [44]:

$$
i_{c o r r}=\frac{b_{a} b_{c}}{2.3\left(b_{a}+b_{c}\right)} \times \frac{1}{R_{P}}
$$

Define:

$$
B=\frac{b_{a} b_{c}}{2.3\left(b_{a}+b_{c}\right)}
$$

Therefore,

$$
i_{c o r r}=\frac{B}{R_{p}}
$$

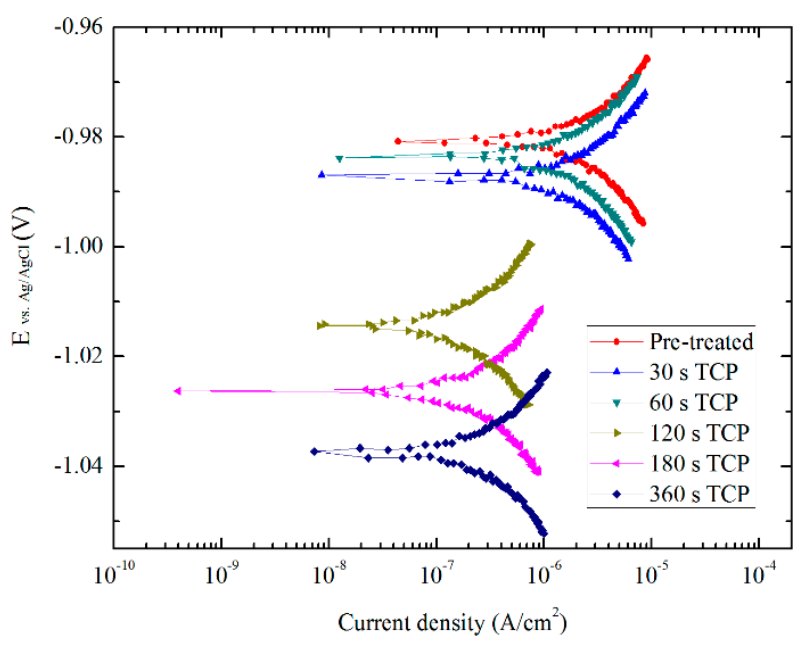

Figure 8. Linear polarization curves of TCCs with different treatment times in aerated $0.5 \mathrm{M}$ $\mathrm{NaCl}$ solution. 
In general, the value of $B$ is ranging from 17 to $26 \mathrm{mV}$ [45]. Under the condition of a micro-polarization test, the values of $b_{a}$ and $b_{c}$ cannot be obtained by linear extrapolation method in the Tafel region. Therefore, the weak polarization curves of the $\mathrm{Zn} 55 \mathrm{Al}$ sample after $180 \mathrm{~s}$ TCP treatment and pre-treated $\mathrm{Zn} 55 \mathrm{Al}$ sample were measured in $0.5 \mathrm{M} \mathrm{NaCl}$ solution with the same scanning rate and electrochemical parameters. The values of $b_{a}$ and $b_{c}$ were obtained by non-linear fitting results based on a polarization curve equation with a range of $\sim \pm 60 \mathrm{mV}$ near the $E_{\text {ocp }}$ and the $B$ was calculated using Equation (3) [46]. For TCP treated samples, the value of $B_{T C P}$ is different from that of the pre-treated sample $\left(B_{0}\right)$, and its value will not change much for TCCs under other film-forming periods. In this paper, defined $B_{0}$ and $B_{T C P}$ as a constant based on the calculated results, i.e., 19 and $22 \mathrm{mV}$ respectively, and the approximate values of current density of $\mathrm{Zn} 55 \mathrm{Al}$ samples in $0.5 \mathrm{M} \mathrm{NaCl}$ solution were calculated by Equation (4) [47]. The polarization resistance $\left(R_{p}\right)$, corrosion potential $\left(E_{\text {corr }}\right)$, corrosion current density $\left(i_{\text {corr }}\right)$ from Figure 8 are summarized in Table 1.

Table 1. Electrochemical parameters obtained from polarization curves shown in Figure 8.

\begin{tabular}{cccc}
\hline Specimens & $\boldsymbol{R}_{\boldsymbol{p}}(\boldsymbol{\Omega})$ & $\boldsymbol{i}_{\text {corr }}\left(\mathrm{A} / \mathrm{cm}^{2}\right)$ & $\boldsymbol{E}_{\text {corr }}(\mathrm{V})$ \\
\hline Pre-treated & $1.7675 \times 10^{3}$ & $1.0750 \times 10^{5}$ & -0.981 \\
TCP for 30 s & $2.1773 \times 10^{3}$ & $1.0104 \times 10^{5}$ & -0.987 \\
TCP for 60 s & $2.2851 \times 10^{3}$ & $9.6276 \times 10^{6}$ & -0.984 \\
TCP for $120 \mathrm{~s}$ & $1.7180 \times 10^{4}$ & $1.2806 \times 10^{6}$ & -1.014 \\
TCP for $180 \mathrm{~s}$ & $2.2487 \times 10^{4}$ & $9.7834 \times 10^{7}$ & -1.026 \\
TCP for 360 s & $1.4671 \times 10^{4}$ & $1.4996 \times 10^{6}$ & -1.037 \\
\hline
\end{tabular}

As revealed by Table 1, by comparing the polarization resistance of $\mathrm{Zn} 55 \mathrm{Al}$ specimens under different treatment conditions, the $R_{p}$ value significantly increased with the prolonging of the TCP-treatment time, and Zn55Al specimen treated by TCP for $180 \mathrm{~s}$ at $40^{\circ} \mathrm{C}$ revealed the highest $R_{p}$ value. The $R_{p}$ values of TCC formed by 180 and $360 \mathrm{~s}$ are one order of magnitude larger than that of the pre-treated specimen, and the values of corrosion current density are nearly one order of magnitude lower than that of the latter accordingly. Therefore, the Zn55Al surface treated in the TCP bath for $180 \mathrm{~s}$ revealed a better anticorrosive performance compared to other treatment time. However, the $R_{p}$ value of the specimen treated for $360 \mathrm{~s}$ in the TCP bath decreased again, and the corrosion current density increased slightly to $1.4996 \times 10^{-6} \mathrm{~A} / \mathrm{cm}^{2}$. For $\mathrm{Zn} 55 \mathrm{Al}, 180 \mathrm{~s}$ is a suitable experimental parameter for TCP treatment, and the TCC film forming effect is the best at this time. Excessive treatment time will bring additional defects such as micro-cracks on the surface, and descends the corrosion resistance of the specimen surface.

\subsection{Surface Composition Analysis}

\subsubsection{Composition of Coating from EDS/AES}

EDS elemental distributions maps of aluminum, zinc, oxygen, zirconium, fluorine, carbon, silicon, and chromium marked with rectangle were displayed in Figure 9. Because the detection depth of EDS is micron level and can only be scanned in a certain depth of field, so the element distribution in the inter-dendritic zone cannot be well displayed and the element beneath the TCC can also be detected. However, in the transition zone between dendrites and interdendrites, the distribution of oxygen, zirconium and chromium appears to be higher than that in other regions (marked in the EDS mapping of element $\mathrm{Zr}$ and $\mathrm{O}$ ), which indicates that TCC thickness here is larger, and the transition zone is the area where the micro-cracks mentioned are more dense. 


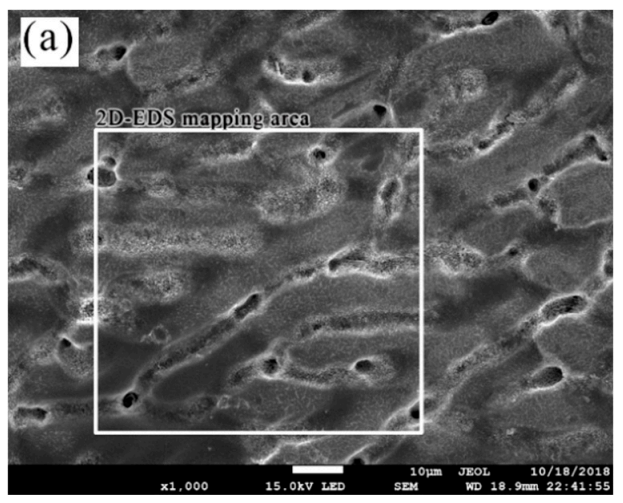

(b)
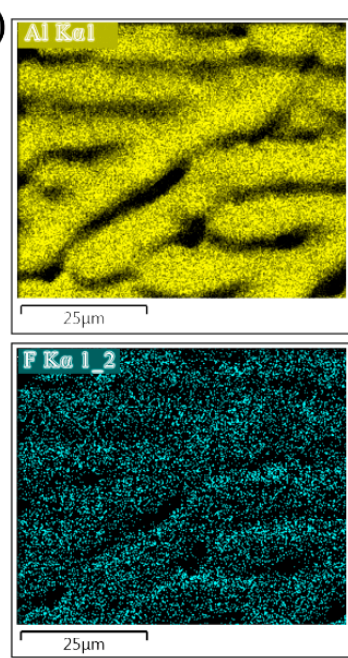
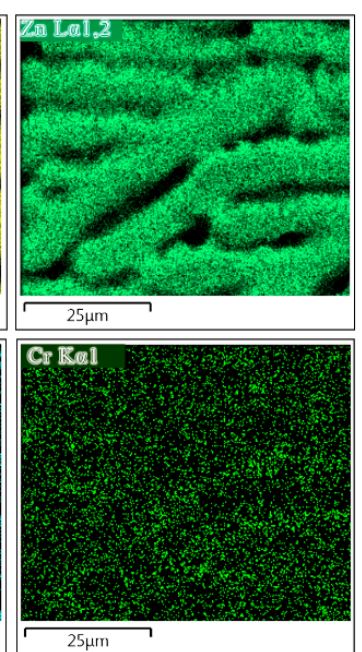
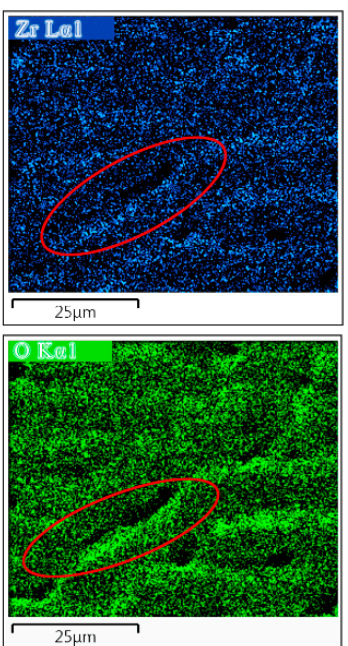
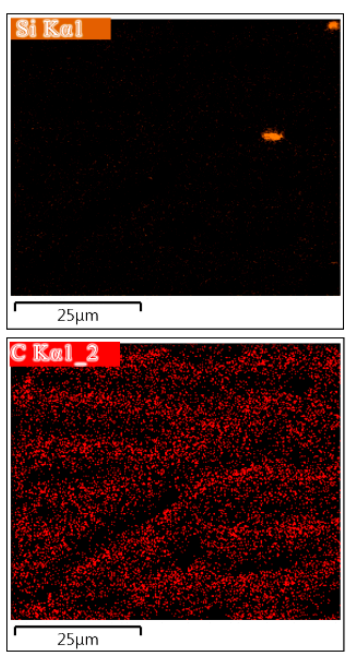

Figure 9. (a) SEM morphology of a $180 \mathrm{~s}$ formed TCC on Zn55Al and (b) 2D-EDS elemental maps of Al, $\mathrm{Zn}, \mathrm{Zr}, \mathrm{Cr}, \mathrm{F}, \mathrm{Si}, \mathrm{C}$ and $\mathrm{O}$ performed over the area on the specimen marked with red dotted rectangle as indicated in Figure 9a.

The SEM morphologies of the specimen sputtered for 0, 10, and 30 min are shown in Figure 10. With the increase of sputtering depth, more micro-cracks were exposed, indicating that TCC with $180 \mathrm{~s}$ film formation time followed by storage in ambient air for at least $24 \mathrm{~h}$ on $\mathrm{Zn} 55 \mathrm{Al}$ surface has a porous character within a certain surface thickness.
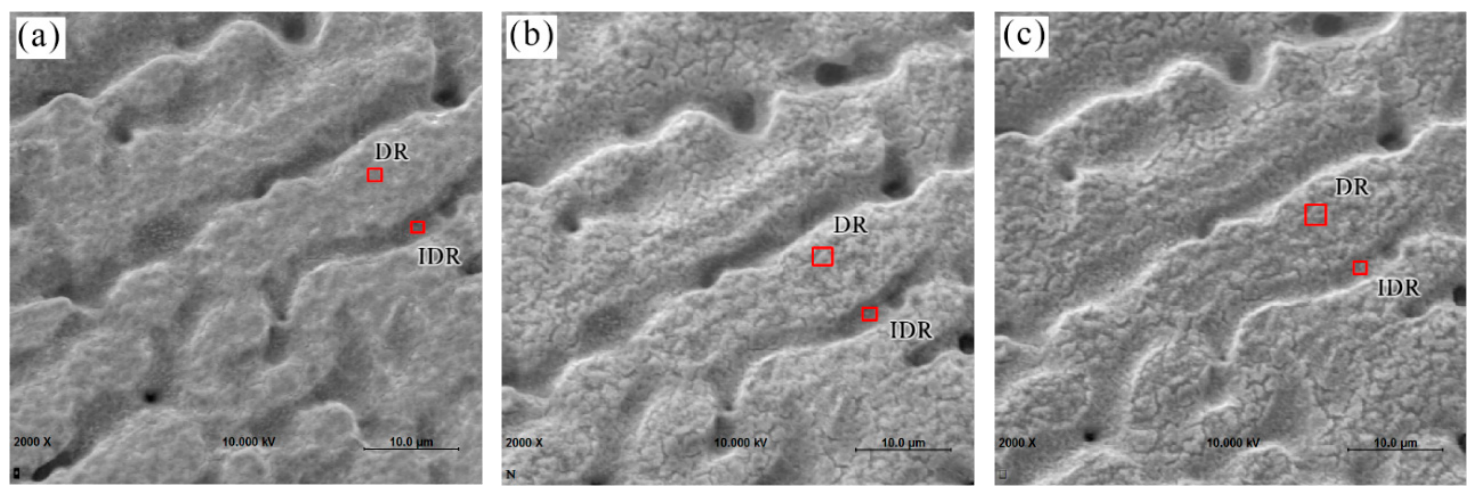

Figure 10. SEM micrograph of the TCCs on $\mathrm{Zn} 55 \mathrm{Al}$ with different $\mathrm{Ar}^{+}$ion sputtering time: (a) 0 min; (b) $10 \mathrm{~min}$; (c) $30 \mathrm{~min}$. The detection positions of AES depth profile in dendritic and inter-dendritic regions are also marked respectively.

The AES elemental atomic in-depth distribution of typical dendritic region (DR) and inter-dendritic region (IDR) (marked in Figure 10) on Zn55Al surface treated by TCP for $180 \mathrm{~s}$ is given in Figure 11. 
The depth information of AES profile is obtained by calculating sputtering rate and sputtering time. Except the element of carbon, the concentration of film-forming elements such as chromium, zirconium, and oxygen increased gradually since $\sim 10 \mathrm{~nm}$.
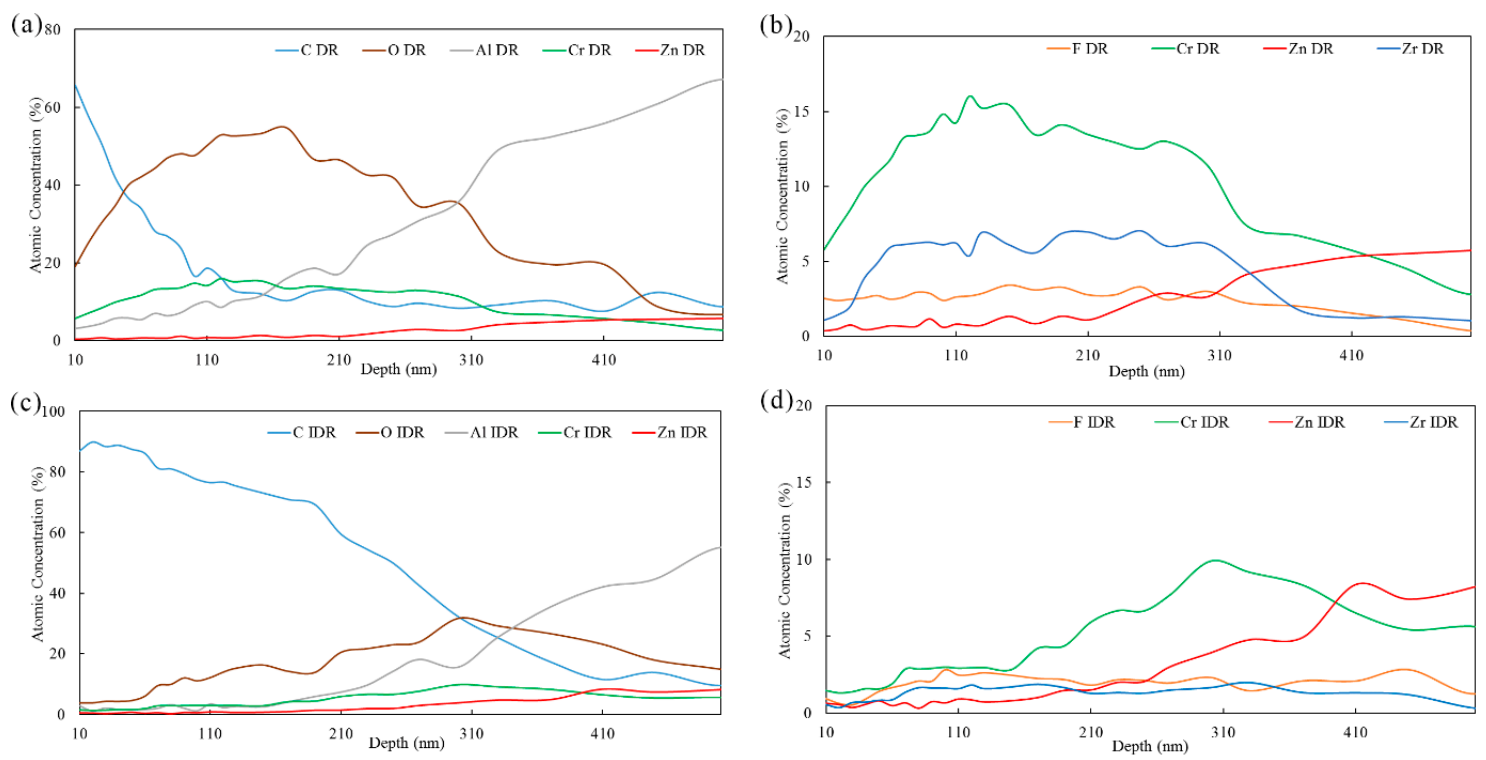

Figure 11. AES elemental atomic in-depth distribution of selected points on TCC formed by $180 \mathrm{~s}$ at $40{ }^{\circ} \mathrm{C}$ in the TCP bath: $(\mathbf{a}, \mathbf{b})$ dendritic region and $(\mathbf{c}, \mathbf{d})$ inter-dendritic region.

According to the distribution trends of chromium and zirconium in Figure $11 \mathrm{~b}$ and oxygen in Figure 11a, it can be deduced that the main part of the TCC in dendritic region is ranging from 50 to $310 \mathrm{~nm}$ beneath the surface. This elemental in-depth distribution results indicate that TCC at dendritic region is not a single structure, but has a multilayer structure. At more significant depths, judging by the increasing contents of $\mathrm{Al}$ and $\mathrm{Zn}$ and the decreasing contents of other TCC film-forming elements such as $\mathrm{Cr}$ and $\mathrm{Zr}$, it can be concluded that the interfacial layer near the substrate is $\mathrm{Al}$ and $\mathrm{Zn}$ rich $[23,24]$. This stratification phenomenon has also been reported by AES analysis of chemical conversion coatings on AA6014 and AA7075 aluminum alloys, in which a bilayer structure was also detected [28,32,35,41].

The ratio of $\mathrm{Cr} / \mathrm{Zr}$ is also an important parameter since these elements co-precipitate to form the coating [33]. It is noteworthy that in the dendritic region, the $\mathrm{Cr} / \mathrm{Zr}$ atomic ratio ranged from 1.85 to 2.98 in the main part of the TCC and the maximum value of this ratio occurs at the depth of $120 \mathrm{~nm}$, which is larger compared to the reported XPS results (i.e., 0.45) of TCCs formed on the surface of AA 2024 aluminum alloy $[42,48]$.

In the inter-dendritic region, the contents of chromium, zirconium, and oxygen reached their maximum value at $300 \mathrm{~nm}$. The ratio of $\mathrm{Cr} / \mathrm{Zr}$ increased from $\sim 1.86$ at $50 \mathrm{~nm}$ depth to $5.92 \mathrm{at} 300 \mathrm{~nm}$, slightly larger than that at dendritic region. Figure $11 \mathrm{c}, \mathrm{d}$ show that the element zinc and aluminum reached a larger content at $\sim 410 \mathrm{~nm}$, indicating that the main distribution of TCC at the inter-dendritic region was slightly thicker than that in dendritic region. However, the stratification phenomenon in the inter-dendritic zone is not as obvious as that in the dendritic zone. As an important participant in TCC formation, fluorine is widely distributed in the conversion coating. In addition, the carbon content detected in the surface layer of TCC in the inter-dendritic zone is very high, the probably reason can be attributed to carbon-based contaminations [28]. But specific reasons need to be further studied.

\subsubsection{Chemical States of TCC Species from XPS}

XPS were carried out on a typical specimen treated by TCP bath for $180 \mathrm{~s}$ followed by the storage at ambient air for at least $24 \mathrm{~h}$. Figure 12 shows the overview XPS spectra acquired from the TCC on 
$\mathrm{Zn} 55 \mathrm{Al}$ surface and the overview spectrum shows strong signals for $\mathrm{Zr}, \mathrm{O}$, and $\mathrm{F}$. This indicates that the main components of TCC are oxides and fluorides, and in addition to chromium, zirconium also participates in the formation of TCC.

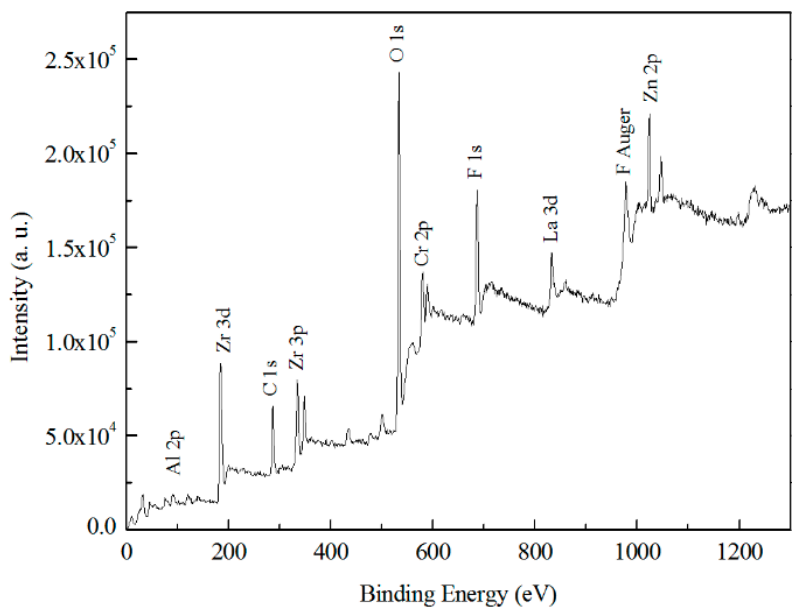

Figure 12. XPS survey scan of a selected Zn55Al specimen treated by TCP for $180 \mathrm{~s}$ at $40^{\circ} \mathrm{C}$ in $\mathrm{TCP}$ bath.

Figure 13 shows the high-resolution spectra for $\mathrm{Cr} 2 p^{3 / 2}$ photoelectron regions. Four peaks were used to fit intensity in the region of 570.0 to $585.0 \mathrm{eV}$, including $\mathrm{Cr}(\mathrm{OH})_{3}(577.2 \pm 0.2 \mathrm{eV}), \mathrm{Cr}_{2} \mathrm{O}_{3}$ $(578.2 \pm 0.2 \mathrm{eV}), \mathrm{CrF}_{3}(580.1 \pm 0.2 \mathrm{eV})$ and $\mathrm{Cr}(\mathrm{VI})$ oxides $(579.6 \pm 0.2 \mathrm{eV})[23,25]$. According to peak fitting results, at the depth of $5 \mathrm{~nm}$ below the surface of TCC, $\sim 25.18 \%$ of $\mathrm{Cr}$ exists in the form of $\mathrm{Cr}_{2} \mathrm{O}_{3}$, $\sim 44.92 \%$ in the form of $\mathrm{CrF}_{3}$, while the content of $\mathrm{Cr}(\mathrm{OH})_{3}$ is only $\sim 9.45 \%$. In addition, $\sim 20.45 \%$ of chromium exists in the form of $\mathrm{Cr}(\mathrm{VI})$, which indicates that $\mathrm{Cr}(\mathrm{VI})$ appears on the TCC surface formed on $\mathrm{Zn} 55 \mathrm{Al}$ exposed to acquired air and other media. Li et al. reported that the $\mathrm{Cr}(\mathrm{VI})$ forms due to the oxidation of $\mathrm{Cr}(\mathrm{III})$ oxide by locally produced $\mathrm{H}_{2} \mathrm{O}_{2}$ at cathodic areas on the substrate [49].

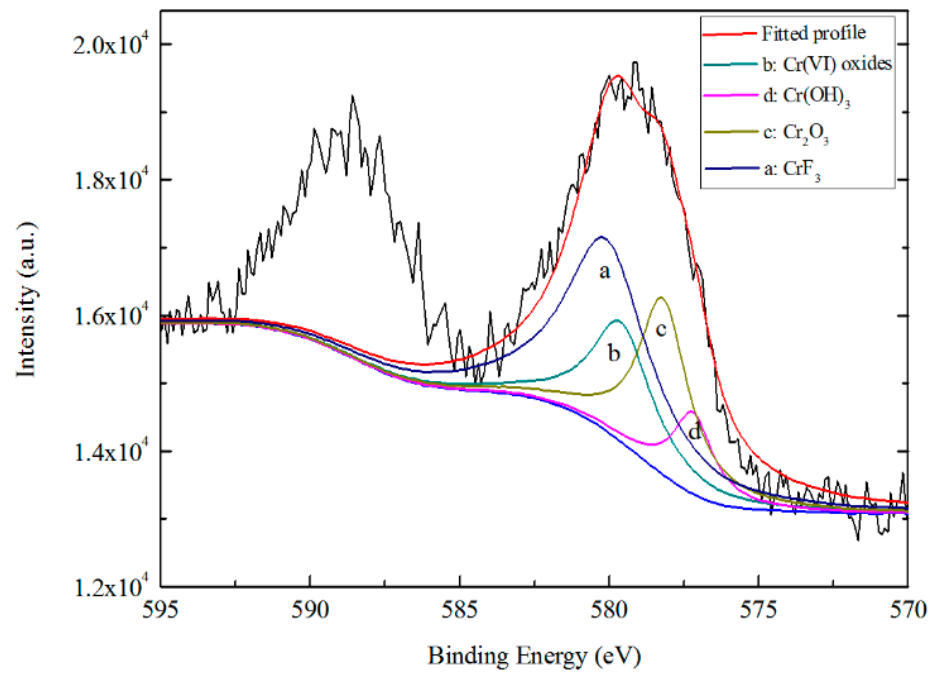

Figure 13. High resolution XPS spectrum and curve fitting for $\mathrm{Cr} 2 p$ photoelectron region for a TCC formed on $\mathrm{Zn} 55 \mathrm{Al}$ for $180 \mathrm{~s}$ in TCP bath at $40^{\circ} \mathrm{C}$. 
The high resolution spectrum of the $\mathrm{Zr} 3 d$ region, including two spin orbit split doublets of $\mathrm{Zr} 3 d^{5 / 2}$ and $\mathrm{Zr} 3 d^{3 / 2}$, shown in Figure 14, was fitted by $\mathrm{ZrO}_{2}(185.3 \pm 0.2 \mathrm{eV})$ for $\mathrm{Zr} 3 d^{3 / 2}, \mathrm{ZrO}_{2}(182.9 \pm 0.2 \mathrm{eV})$ for $\mathrm{Zr} \mathrm{3} d^{5 / 2}$ [13,50], $\mathrm{ZrF}_{4}(184.5 \pm 0.2 \mathrm{eV})$ [51] and $\mathrm{Zr}(\mathrm{OH})_{4}(184.0 \pm 0.2 \mathrm{eV})$ for $\mathrm{Zr} \mathrm{3} d^{5 / 2}$ [42]. About $\sim 69.61 \%, \sim 29.94 \%$ and $\sim 0.46 \%$ of the zirconium were in the form of oxide, fluoride and hydroxide, respectively. This indicates that $\mathrm{Zr}$ on the surface of TCC mostly exists in the form of oxides, and proves that the formation of $\mathrm{ZrO}_{2}$ complies with the following chemical equation [34,49,52]:

$$
\mathrm{ZrF}_{6}^{2-}+4 \mathrm{H}_{2} \mathrm{O} \rightarrow \mathrm{ZrO}_{2} \cdot \mathrm{H}_{2} \mathrm{O}+6 \mathrm{HF}+\mathrm{O}^{2-}
$$

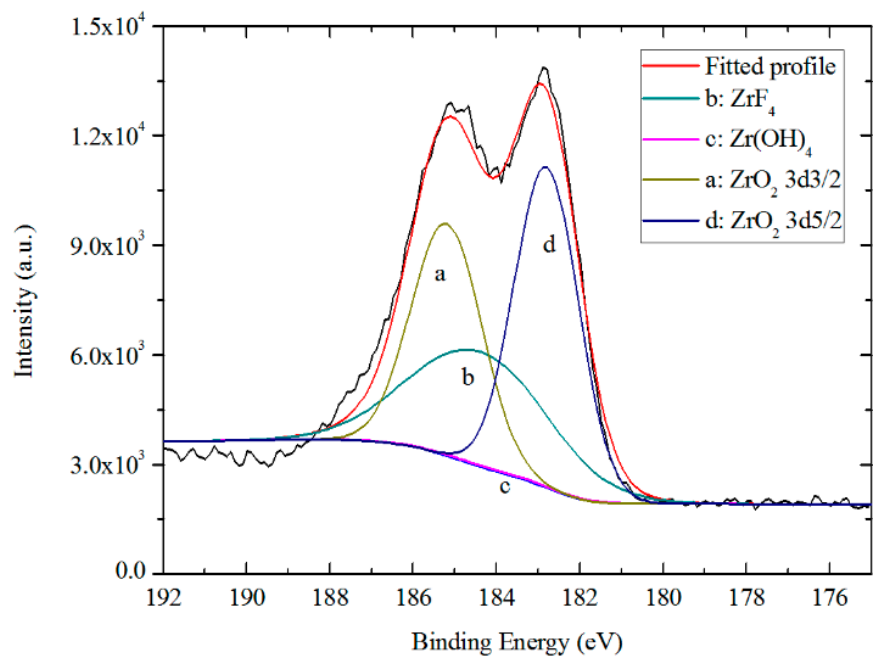

Figure 14. High resolution XPS spectrum and curve fitting for Zr $3 d$ photoelectron region for a TCC formed on $\mathrm{Zn} 55 \mathrm{Al}$ for $180 \mathrm{~s}$ in TCP bath at $40^{\circ} \mathrm{C}$.

As reported by previous research, hexafluorozirconate in the TCP bath plays an important role in the whole process of TCC film formation. The hydrolysis of $\mathrm{ZrF}_{6}{ }^{2-}$ is the beginning of the whole chemical conversion and leads to formation of a fresh hydrated layer and results in activation of the surface, lowering of the corrosion potential and increasing in the hydrophilicity of the surface $[24,35,53]$. From Figure 11, zirconium containing compounds are concentrated in the middle depth of the TCC, which means $\mathrm{Zr}$ is the main participant in the formation of TCC both within the inter-dendritic and dendritic regions.

Figures 15 and 16 show the high resolution XPS spectra from the $\mathrm{Al} 2 p^{3 / 2}$ and $\mathrm{Zn} 2 p^{3 / 2}$ regions. The presence of $\mathrm{Al}_{2} \mathrm{O}_{3}, \mathrm{Al}(\mathrm{OH})_{3}$ and $\mathrm{AlF}_{3}$ is indicated by the $\mathrm{Al} 2 p$ peaks at $74.7,75.7$, and $76.3 \mathrm{eV}$, respectively [23,54-56]. The fitting of the $\mathrm{Zn} 2 p$ peaks was achieved with a $\mathrm{Zn}(\mathrm{OH})_{2}$ peak at $1022.7 \mathrm{eV}$, a $\mathrm{ZnSO}_{4}$ peak at $1023.1 \mathrm{eV}$ [57], a $\mathrm{ZnF}_{2}$ peak at $1022.8 \mathrm{eV}$ [58] and a $\mathrm{ZnO}$ peak at $1021.9 \mathrm{eV}$ [59]. In the outer $\approx 5 \mathrm{~nm}$ of the coating thickness, all the content of $\mathrm{Al}_{2} \mathrm{O}_{3}$ and $\mathrm{Al}(\mathrm{OH})_{3}$ are $\sim 21.87 \%$, and the content of $\mathrm{AlF}_{3}$ is $\sim 56.26 \%$. The results of $\mathrm{Zn} 2 p^{3 / 2}$ are different from that of $\mathrm{Al} 2 p^{3 / 2}$. Except $\sim 46.84 \%$ of $\mathrm{Zn}(\mathrm{OH})_{2}$ and $\sim 8.41 \%$ of $\mathrm{ZnF}_{2}$, no obvious $\mathrm{ZnO}$ has been revealed $(\sim 0.36 \%)$, and the possible $\mathrm{ZnSO}_{4}$ has appeared in the fitted results, the proportion of which is $\sim 39.58 \%$. The presence of $\mathrm{ZnSO}_{4}$ may be a residue of the combination of oxidized $\mathrm{Zn}^{2+}$ and $\mathrm{SO}_{4}{ }^{2-}$ ions in diluted TCP bath, and the fitting result at the $\mathrm{Zn} 2 p^{1 / 2}$ region (1046.2 eV) is also in agreement with this conclusion. 


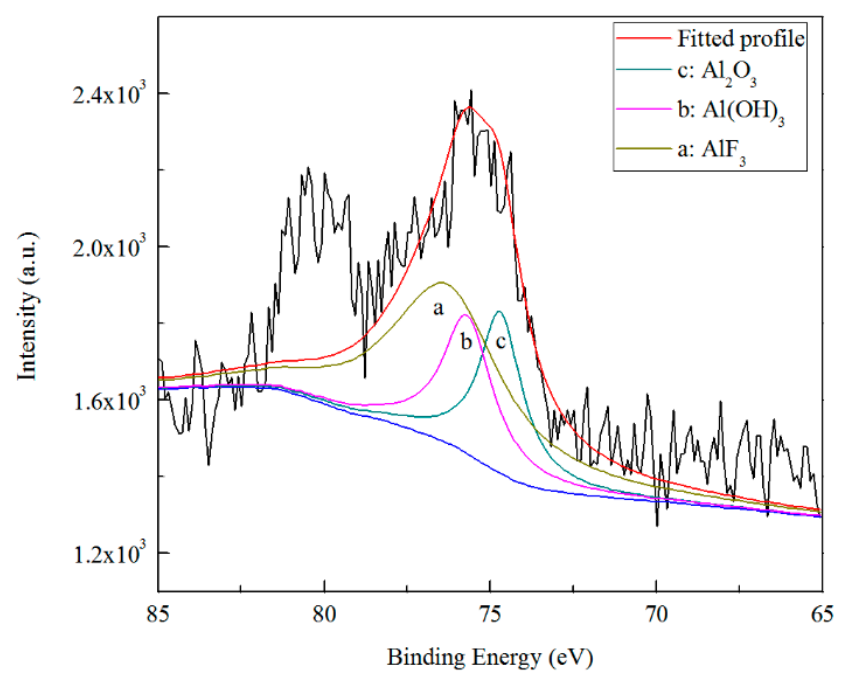

Figure 15. High resolution XPS spectrum and curve fitting for $\mathrm{Al} 2 p$ photoelectron region for a TCC formed on $\mathrm{Zn} 55 \mathrm{Al}$ for $180 \mathrm{~s}$ in TCP bath at $40{ }^{\circ} \mathrm{C}$.

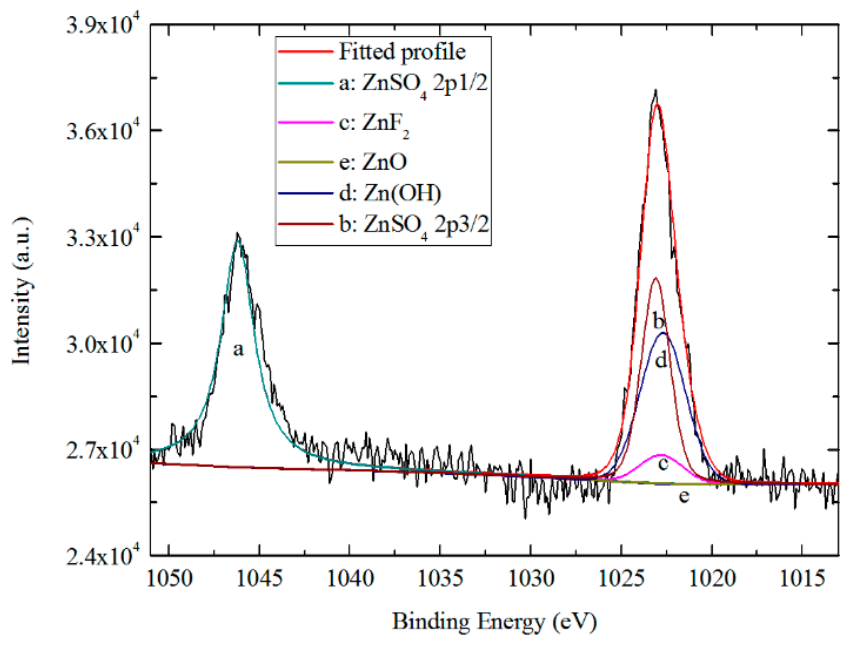

Figure 16. High resolution XPS spectrum and curve fitting for $\mathrm{Zn} 2 p$ photoelectron region for a TCC formed on $\mathrm{Zn} 55 \mathrm{Al}$ for $180 \mathrm{~s}$ in TCP bath at $40^{\circ} \mathrm{C}$.

\section{Discussion}

The effects of treatment time on surface morphology, composition, roughness, corrosion resistance, and adhesion of epoxy primer of $\mathrm{Zn} 55 \mathrm{Al}$ were investigated in the present work and it has been proven that the trivalent chromium conversion coating can improve the corrosion resistance of the matrix in an aggressive electrolyte solution and the adhesion of the primer, and the optimum film formation time is $180 \mathrm{~s}$ at $40{ }^{\circ} \mathrm{C}$ in a diluted $\mathrm{Cr}$ (III)-based solution.

On one hand, the process of $\mathrm{Cr}$ (III)-based conversion treatment remarkably improves the adhesion of primer as compared to the untreated Zn55Al surface as shown by the measurement of the pull-off bonding strength. This coincided with the results of the aluminum alloy samples modified with Zr-based conversion coatings [14]. In Figure 3, the roughness of Zn55Al surface decreased by $~ 14.56 \%$ in the short period of $30 \mathrm{~s}$ after TCP treatment compared with that of untreated, showing the strong etching and leveling effect of TCP on Zn55Al surface. However, as illustrated by Figure 5, in both dendritic and inter-dendritic regions, TCP treatment results in an increase in surface roughness of $\mathrm{Zn} 55 \mathrm{Al}$ by nanometric micro-scale, which in turn improves the mechanical inter-locking between the epoxy primer and the substrate [11,14,60]. Figure 17 shows the photographs of $4 \mu \mathrm{L}$ water droplets on the TCP treated $\mathrm{Zn} 55 \mathrm{Al}$ sheets. The water contact angle of TCP treated samples gradually decreased 
with the extension of TCP treatment time, as a result of the reduction of apparent surface energy [60]. The epoxy coating has polar nature due to the presence of ether and hydroxyl groups in its chemical structure. The hydrophilicity of the TCP treated specimen helps the establishment of stronger adhesive polar-polar bonds between the epoxy coating and modified substrate instead of the original weak physical bonds, such as hydrogen bond or van der Waals force $[8,61]$.

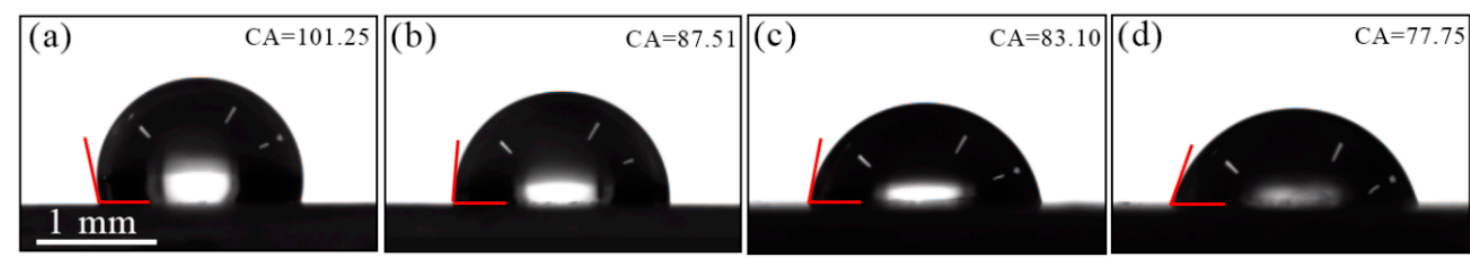

Figure 17. The contact angle of $4 \mu \mathrm{L}$ water droplets on the TCP-treated $\mathrm{Zn} 55 \mathrm{Al}$ sheets with different immersion periods: (a) $0 \mathrm{~s}$; (b) $30 \mathrm{~s}$; (c) $60 \mathrm{~s}$ and (d) $180 \mathrm{~s}$.

On the other hand, according to the electrochemical results in Figure 8 and Table 1, TCP generated at $180 \mathrm{~s}$ has an attenuated corrosion current density, which corresponds to the maximum polarization resistance. Compared with the $\mathrm{Zn} 55 \mathrm{Al}$ specimen only pretreated by alkaline washing and pickling, the corrosion current density decreased by one orders of magnitude after TCP treatment for $180 \mathrm{~s}$.

It has been reported that the conversion coatings provide cathodic protection on aluminum, zinc, and hot-dip galvanized steel [62-64]. In near-neutral aggressive electrolyte solutions with and without oxygen, as shown in Figure 18, the cathodic polarization curves of $\mathrm{Zn} 55 \mathrm{Al}$ specimens were compared in this part. The cathodic corrosion current density of uncoated $\mathrm{Zn} 55 \mathrm{Al}$ specimen at corrosion potential is much smaller in the de-aerated $0.05 \mathrm{M} \mathrm{NaCl}$ solution, compared with the current density in the aerated solution. Therefore, the corrosion of $\mathrm{Zn} 55 \mathrm{Al}$ surfaces takes place under cathodic control, and the reduction in the corrosion rate can be brought about by inhibiting the oxygen depolarization corrosion on bare $\mathrm{Zn} 55 \mathrm{Al}$ surface [65]:

$$
\mathrm{O}_{2}+4 \mathrm{H}^{+}+4 \mathrm{e}^{-} \rightarrow 2 \mathrm{H}_{2} \mathrm{O} \text { (in aerated solution) }
$$

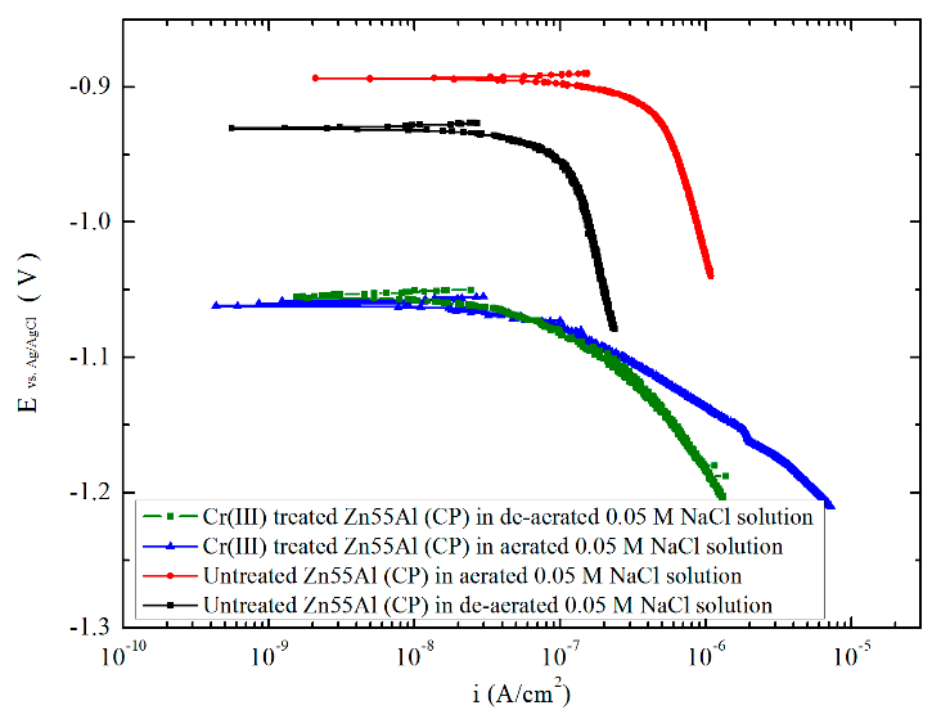

Figure 18. Cathodic polarization curves for $\mathrm{Zn} 55 \mathrm{Al}$ specimens with and without TCP treatment in de-aerated or aerated $0.05 \mathrm{M} \mathrm{NaCl}$ solution.

In order to evaluate the anticorrosion property of TCC on Zn55Al, cathodic polarization curves were also measured on specimens treated by $180 \mathrm{~s}$ at $40^{\circ} \mathrm{C}$ in the TCP bath. As shown in Figure 18 and 
Table 2, cathodic current at potentials close to $E_{\text {corr }}$ measured on $\mathrm{Cr}$ (III) treated $\mathrm{Zn} 55 \mathrm{Al}$ specimen in the aerated $0.05 \mathrm{M} \mathrm{NaCl}$ solution is significantly smaller than that on the uncoated specimen, to an extend of an order of magnitude (with $2.13 \times 10^{-7}$ and $4.81 \times 10^{-8} \mathrm{~A} / \mathrm{cm}^{2}$ separately). Hence, it is clear that $\mathrm{Cr}(\mathrm{III})$ coatings formed an effective physical barrier layer which hindered the transportation of oxygen and corrosive chloride ions to the Zn55Al substrate, and the corrosion of Zn55Al can be retarded. However, as shown in Figure 5, the effect of TCC as a corrosion barrier does not increase with the prolongation of TCP treatment time due to the micro-cracks on TCC surface that is most commonly observed [24]. This result is consistent with previous reports by Golru et al., that is, the AA1050 aluminum alloy specimens treated in a zirconium-based bath at an immersion time greater than 3 min did not shown a better corrosion resistance [14].

Table 2. Fitting results of cathodic polarization curves recorded in Figure 17.

\begin{tabular}{cccc}
\hline Specimens & Curve & $\boldsymbol{E}_{\text {corr }}(\mathbf{V})$ & $\boldsymbol{i}_{\text {corr }} \mathbf{( A / \mathbf { c m } ^ { 2 } )}$ \\
\hline $\begin{array}{c}\text { Uncoated Zn55Al in } \\
\text { aerated } 0.05 \mathrm{M} \mathrm{NaCl}\end{array}$ & $\mathrm{CP}$ & -0.8936 & $2.13 \times 10^{-7}$ \\
$\begin{array}{c}\text { Uncoated Zn55Al in } \\
\text { de-aerated } 0.05 \mathrm{M} \mathrm{NaCl}\end{array}$ & $\mathrm{CP}$ & -0.9305 & $5.21 \times 10^{-8}$ \\
$\begin{array}{c}\mathrm{Cr}(\mathrm{III}) \text { treated } \mathrm{Zn} 55 \mathrm{Al} \text { in } \\
\text { aerated } 0.05 \mathrm{M} \mathrm{NaCl}\end{array}$ & $\mathrm{CP}$ & -1.0598 & $4.81 \times 10^{-8}$ \\
$\begin{array}{c}\text { Cr(III) treated Zn55Al in } \\
\text { de-aerated } 0.05 \mathrm{M} \mathrm{NaCl}\end{array}$ & $\mathrm{CP}$ & -1.0432 & $7.72 \times 10^{-8}$ \\
\hline
\end{tabular}

Previous studies have shown that the kinetics of chemical conversion film formation is the increase of $\mathrm{pH}$, and the initial hydroxyl framework on the surface also plays an important role in subsequent film formation $[29,66]$. With the increase of $\mathrm{pH}$ at the newly formed TCP surface (from 2.6 to 9), the reaction kinetics decrease gradually [24]. Due to the low $\mathrm{pH}$ of TCP bath, the oxidation reaction of Al-rich dendritic regions takes place first:

$$
\mathrm{Al} \rightarrow \mathrm{Al}^{3+}+3 \mathrm{e}^{-}
$$

The dissolved $\mathrm{Al}^{3+}, \mathrm{Cr}^{3+}$ and $\mathrm{Zn}^{2+}$ ions are precipitated into $\mathrm{Al}(\mathrm{OH})_{3}, \mathrm{Cr}(\mathrm{OH})_{3}$ and $\mathrm{Zn}(\mathrm{OH})_{2}$ by combining with $\mathrm{OH}^{-}$ions generated by the reduction of dissolved oxygen and hydrogen evolution $[13,67]$ :

$$
\begin{gathered}
2 \mathrm{H}^{+}+2 \mathrm{e}^{-} \rightarrow \mathrm{H}_{2} \\
\mathrm{O}_{2}+2 \mathrm{H}_{2} \mathrm{O}+4 \mathrm{e}^{-} \rightarrow 4 \mathrm{OH}^{-}
\end{gathered}
$$

However, the surface of freshly formed TCC is easy to dehydrate in air with prolongation of time, and some hydroxides may dehydrate into oxides. This hypothesis explains the reason why some oxides appear in the XPS fitting results of $\mathrm{Al}$ and $\mathrm{Cr}$. And aluminum-rich region may also be hydrolyzed directly to form $\mathrm{Al}_{2} \mathrm{O}_{3}$, which jointly forms TCP inner layer in dendritic region with $\mathrm{Al}(\mathrm{OH})_{3}[66]$ :

$$
2 \mathrm{Al}+3 \mathrm{H}_{2} \mathrm{O} \rightarrow \mathrm{Al}_{2} \mathrm{O}_{3}+6 \mathrm{H}^{+}+6 \mathrm{e}^{-}
$$

According to AES results as shown in Figure 11c,d, zinc in the inter-dendritic region mainly distributes in the inner layer of TCC, and the content of aluminum is always higher than that of zinc. We speculate that alumina and aluminum hydroxide formed in the dendritic region migrate to the inter-dendritic region shortly after TCC formation, which prevents the continuous precipitation of $\mathrm{Zn}(\mathrm{OH})_{2}$. And the depressions in the inter-dendritic region are filled with precipitated particles formed during film formation. This is consistent with the result that no $\mathrm{ZnO}$ appears in the analysis of XPS at the depth of $\sim 5 \mathrm{~nm}$. However, Lostak et al. observed that upon immersion in diluted conversion solution for rather short times of up to $40 \mathrm{~s}$ the deposition of TCC starts to take place preferentially on the local Zn-rich cathodes of Zn-Al-Mg alloy coated steel [68]. Therefore, it can be inferred that 
the transition region between dendrite region and inter-dendrite region has the thickest TCC and the maximum film forming power. This conclusion accords with the phenomenon observed in Figure $5 \mathrm{~d}$, because the thicker the film layer is, the greater the tendency of forming larger micro-cracks in the later stage.

Element of $\mathrm{F}$ was identified throughout the coatings, validating the role of this element in the formation mechanism. The mechanism of the $\mathrm{AlF}_{3}$ and $\mathrm{ZnF}_{2}$ deposition throughout the whole TCC may raise the assumption that during the TCC formation the free $\mathrm{F}^{-}$ions dissolve the $\mathrm{Zn}(\mathrm{OH})_{2}$ and $\mathrm{Al}_{2} \mathrm{O}_{3}$ as represented by the following reaction $[29,69]$ :

$$
\begin{gathered}
\mathrm{Zn}(\mathrm{OH})_{2}+x \mathrm{~F}^{-} \rightarrow \mathrm{ZnF}_{x}^{(2-x)}+2 \mathrm{OH}^{-} \\
\mathrm{Al}_{2} \mathrm{O}_{3}+x \mathrm{~F}^{-}+6 \mathrm{H}^{+} \rightarrow 2 \mathrm{AlF}_{x}^{(3-x)}+3 \mathrm{H}_{2} \mathrm{O}
\end{gathered}
$$

\section{Conclusions}

Both of the characterizations by surface analysis and electrochemical measurements indicate that $\mathrm{Zn} 55 \mathrm{Al}$ treated in a dilute $\mathrm{Cr}$ (III) bath at $40^{\circ} \mathrm{C}$ for $180 \mathrm{~s}$ has the optimum performance in terms of the polarization resistance and adhesion strength to epoxy primer. The following conclusions can be drawn:

- The analysis of 3D morphology and roughness shows that the macro-roughness of Zn55Al specimen surface decreases gradually with the prolongation of TCP treatment time. The surface roughness of $\mathrm{Zn} 55 \mathrm{Al}$ treated for $180 \mathrm{~s}$ in $\mathrm{Cr}(\mathrm{III})$-based dilution commercial solution at $40{ }^{\circ} \mathrm{C}$ is $\sim 57 \%$ lower than that of the untreated surface. However, the formation of TCC results in the increase of the micro-roughness of the $\mathrm{Zn} 55 \mathrm{Al}$ surface in contrast to the untreated specimen, which enhances the adhesion of the coating, and the film formation begins at the transition zone between dendrites and dendrites.

- Pull-off adhesion strength tests revealed that the $\mathrm{Cr}(\mathrm{III})$ conversion coating improved the adhesion of the epoxy primer on Zn55Al by $31.8 \%$ after TCP treatment of $180 \mathrm{~s}$, which may be attributed to the increase of micro-roughness and the physicochemical properties of TCC.

- $\quad$ AES depth profiling indicates the trivalent conversion coating on Zn55Al treated by TCP for $180 \mathrm{~s}$ consists of a bilayer structure in the dendritic and inter-dendritic regions. The total thickness of TCC in the inter-dendritic region $(\sim 410 \mathrm{~nm})$ is larger than that in the dendritic region $(\sim 310 \mathrm{~nm})$, which is up to the main film-forming element of zirconium and chromium. The maximum $\mathrm{Cr} / \mathrm{Zr}$ atomic concentration ratio is $\sim 5.92$ at the inter-dendritic region. The chemical states results from XPS revealed that the main chemical components on the TCC surface are oxides and fluorides of $\mathrm{Al}, \mathrm{Zn}, \mathrm{Cr}$, and $\mathrm{Zr}$, with a small number of hydroxides.

- Results of the electrochemical tests show that in an aggressive $0.5 \mathrm{M} \mathrm{NaCl}$ solution, the corrosion resistance of $\mathrm{Zn} 55 \mathrm{Al}$ can be greatly enhanced by TCP treatment. Zn55Al specimens after $180 \mathrm{~s}$ of TCC film formation have the lowest corrosion current density and the largest polarization resistance. The cathodic polarization curves measured in a less aggressive $0.05 \mathrm{M} \mathrm{NaCl}$ solutions indicated that the corrosion of $\mathrm{Zn} 55 \mathrm{Al}$ is cathodic control and the $\mathrm{Cr}$ (III) can act as a barrier for corrosion mass transfer. In addition, the corrosion resistance of $\mathrm{Zn} 55 \mathrm{Al}$ surface treated by TCP is sensitive to surface micro-cracks.

Author Contributions: Conceptualization, J.P. and Y.L.; Methodology, J.P. and Y.L.; Writing-Original Draft Preparation, J.P.; Writing-Review and Editing, J.P., X.T. and Y.L.; Supervision, X.T. and Y.L.; Project Administration, Y.L.

Funding: This research was funded by the Key Research and Development Program of Shandong Province (Grant No. 2017GHY15108) and China University of Petroleum (East China) Independent Innovation Research Project (Grant No. 18CX05021A).

Conflicts of Interest: The authors declare no conflict of interest. 


\section{References}

1. Vu, T.N.; Volovitch, P.; Ogle, K. The effect of $\mathrm{pH}$ on the selective dissolution of $\mathrm{Zn}$ and $\mathrm{Al}$ from $\mathrm{Zn}-\mathrm{Al}$ coatings on steel. Corros. Sci. 2013, 67, 42-49. [CrossRef]

2. Panossian, Z.; Mariaca, L.; Morcillo, M.; Flores, S.; Rocha, J.; Peña, J.J.; Herrera, F.; Corvo, F.; Sanchez, M.; Rincon, O.T.; et al. Steel cathodic protection afforded by zinc, aluminium and zinc/aluminium alloy coatings in the atmosphere. Surf. Coat. Technol. 2005, 190, 244-248. [CrossRef]

3. Tachibana, K.; Morinaga, Y.; Mayuzumi, M. Hot dip fine $\mathrm{Zn}$ and $\mathrm{Zn}-\mathrm{Al}$ alloy double coating for corrosion resistance at coastal area. Corros. Sci. 2007, 49, 149-157. [CrossRef]

4. Moreira, A.R.; Panossian, Z.; Camargo, P.L.; Moreira, M.F.; da Silva, I.C.; de Carvalho, J.E.R. Zn/55Al coating microstructure and corrosion mechanism. Corros. Sci. 2006, 48, 564-576. [CrossRef]

5. Persson, D.; Thierry, D.; Karlsson, O. Corrosion and corrosion products of hot dipped galvanized steel during long term atmospheric exposure at different sites world-wide. Corros. Sci. 2017, 126, 152-165. [CrossRef]

6. $\mathrm{Li}, \mathrm{Y}$. Formation of nano-crystalline corrosion products on $\mathrm{Zn}-\mathrm{Al}$ alloy coating exposed to seawater. Corros. Sci. 2001, 43, 1793-1800. [CrossRef]

7. Vakili, H.; Ramezanzadeh, B.; Amini, R. The corrosion performance and adhesion properties of the epoxy coating applied on the steel substrates treated by cerium-based conversion coatings. Corros. Sci. 2015, 94, 466-475. [CrossRef]

8. Mahidashti, Z.; Shahrabi, T.; Ramezanzadeh, B. The role of post-treatment of an ecofriendly cerium nanostructure conversion coating by green corrosion inhibitor on the adhesion and corrosion protection properties of the epoxy coating. Prog. Org. Coat. 2018, 114, 19-32. [CrossRef]

9. Eivaz Mohammadloo, H.; Sarabi, A.A.; Asemani, H.R.; Ahmadi, P. A comparative study of eco-friendly hybrid thin films: With and without organic coating application. Prog. Org. Coat. 2018, 125, 432-442. [CrossRef]

10. Sababi, M.; Terryn, H.; Mol, J.M.C. The influence of a Zr-based conversion treatment on interfacial bonding strength and stability of epoxy coated carbon steel. Prog. Org. Coat. 2017, 105, 29-36. [CrossRef]

11. Ramezanzadeh, B.; Attar, M.M. An evaluation of the corrosion resistance and adhesion properties of an epoxy-nanocomposite on a hot-dip galvanized steel (HDG) treated by different kinds of conversion coatings. Surf. Coat. Technol. 2011, 205, 4649-4657. [CrossRef]

12. Asemani, H.R.; Ahmadi, P.; Sarabi, A.A.; Eivaz Mohammadloo, H. Effect of zirconium conversion coating: Adhesion and anti-corrosion properties of epoxy organic coating containing zinc aluminum polyphosphate (ZAPP) pigment on carbon mild steel. Prog. Org. Coat. 2016, 94, 18-27. [CrossRef]

13. Mohammad Hosseini, R.; Sarabi, A.A.; Eivaz Mohammadloo, H.; Sarayloo, M. The performance improvement of $\mathrm{Zr}$ conversion coating through Mn incorporation: With and without organic coating. Surf. Coat. Technol. 2014, 258, 437-446. [CrossRef]

14. Sharifi Golru, S.; Attar, M.M.; Ramezanzadeh, B. Effects of surface treatment of aluminium alloy 1050 on the adhesion and anticorrosion properties of the epoxy coating. Appl. Surf. Sci. 2015, 345, 360-368. [CrossRef]

15. Golru, S.S.; Attar, M.M.; Ramezanzadeh, B. Morphological analysis and corrosion performance of zirconium based conversion coating on the aluminum alloy 1050. J. Ind. Eng. Chem. 2015, 24, 233-244. [CrossRef]

16. Ghanbari, A.; Attar, M.M. Surface free energy characterization and adhesion performance of mild steel treated based on zirconium conversion coating: A comparative study. Surf. Coat. Technol. 2014, 246, $26-33$. [CrossRef]

17. Kendig, M.W.; Buchheit, R.G. Corrosion inhibition of aluminum and aluminum alloys by soluble chromates, chromate coatings, and chromate-free coatings. Corrosion 2003, 59, 379-400. [CrossRef]

18. Tomachuk, C.R.; Elsner, C.I.; Di Sarli, A.R.; Ferraz, O.B. Corrosion resistance of Cr(III) conversion treatments applied on electrogalvanised steel and subjected to chloride containing media. Mater. Chem. Phys. 2010, 119, 19-29. [CrossRef]

19. Sheu, H.H.; Lin, C.H.; Jian, S.Y.; Lee, H.B.; Yang, B.R.; Ger, M.D. Effects of complexing agents and current density on carbon content of trivalent chromium carbon coating and its properties. Int. J. Electrochem. Sci. 2016, 11, 7099-7110. [CrossRef]

20. Sheu, H.H.; Lee, H.B.; Jian, S.Y.; Hsu, C.Y.; Lee, C.Y. Investigation on the corrosion resistance of trivalent chromium conversion passivate on electroplated Zn-Ni alloy. Surf. Coat. Technol. 2016, 305, 241-248. [CrossRef] 
21. Taheri, P.; Laha, P.; Terryn, H.; Mol, J.M.C. An in situ study of zirconium-based conversion treatment on zinc surfaces. Appl. Surf. Sci. 2015, 356, 837-843. [CrossRef]

22. Li, L.; Swain, G.M. Effects of aging temperature and time on the corrosion protection provided by trivalent chromium process coatings on AA2024-T3. ACS Appl. Mater. Interfaces 2013, 5, 7923-7930. [CrossRef]

23. Qi, J.T.; Hashimoto, T.; Walton, J.R.; Zhou, X.; Skeldon, P.; Thompson, G.E. Trivalent chromium conversion coating formation on aluminium. Surf. Coat. Technol. 2015, 280, 317-329. [CrossRef]

24. Guo, Y.; Frankel, G.S. Characterization of trivalent chromium process coating on AA2024-T3. Surf. Coat. Technol. 2012, 206, 3895-3902. [CrossRef]

25. Viroulaud, R.; Światowska, J.; Seyeux, A.; Zanna, S.; Tardelli, J.; Marcus, P. Influence of surface pretreatments on the quality of trivalent chromium process coatings on aluminum alloy. Appl. Surf. Sci. 2017, 423, 927-938. [CrossRef]

26. Verdalet-Guardiola, X.; Bonino, J.-P.; Duluard, S.; Fori, B.; Blanc, C. Influence of the alloy microstructure and surface state on the protective properties of trivalent chromium coatings grown on a 2024 aluminium alloy. Surf. Coat. Technol. 2018, 344, 276-287. [CrossRef]

27. Chen, W.-K.; Bai, C.-Y.; Liu, C.-M.; Lin, C.-S.; Ger, M.-D. The effect of chromic sulfate concentration and immersion time on the structures and anticorrosive performance of the $\mathrm{Cr}$ (III) conversion coatings on aluminum alloys. Appl. Surf. Sci. 2010, 256, 4924-4929. [CrossRef]

28. Cerezo, J.; Vandendael, I.; Posner, R.; de Wit, J.H.W.; Mol, J.M.C.; Terryn, H. Initiation and growth of modified Zr-based conversion coatings on multi-metal surfaces. Surf. Coat. Technol. 2013, 236, 284-289. [CrossRef]

29. Cerezo, J.; Taheri, P.; Vandendael, I.; Posner, R.; Lill, K.; de Wit, J.H.W.; Mol, J.M.C.; Terryn, H. Influence of surface hydroxyls on the formation of Zr-based conversion coatings on AA6014 aluminum alloy. Surf. Coat. Technol. 2014, 254, 277-283. [CrossRef]

30. Zhu, W.; Li, W.; Mu, S.; Yang, Y.; Zuo, X. The adhesion performance of epoxy coating on AA6063 treated in Ti/Zr/V based solution. Appl. Surf. Sci. 2016, 384, 333-340. [CrossRef]

31. Cavanaugh, M.K.; Li, J.C.; Birbilis, N.; Buchheit, R.G. Electrochemical characterization of intermetallic phases common to aluminum alloys as a function of solution temperature. J. Electrochem. Soc. 2014, 161, C535-C543. [CrossRef]

32. Munson, C.A.; Swain, G.M. Structure and chemical composition of different variants of a commercial trivalent chromium process (TCP) coating on aluminum alloy 7075-T6. Surf. Coat. Technol. 2017, 315, 150-162. [CrossRef]

33. Munson, C.A.; McFall-Boegeman, S.A.; Swain, G.M. Cross comparison of TCP conversion coating performance on aluminum alloys during neutral salt-spray and thin-layer mist accelerated degradation testing. Electrochim. Acta 2018, 282, 171-184. [CrossRef]

34. Li, L.; Doran, K.P.; Swain, G.M. Electrochemical characterization of trivalent chromium process (TCP) coatings on aluminum alloys 6061 and 7075. J. Electrochem. Soc. 2013, 160, C396-C401. [CrossRef]

35. Fockaert, L.I.; Taheri, P.; Abrahami, S.T.; Boelen, B.; Terryn, H.; Mol, J.M.C. Zirconium-based conversion film formation on zinc, aluminium and magnesium oxides and their interactions with functionalized molecules. Appl. Surf. Sci. 2017, 423, 817-828. [CrossRef]

36. Selverian, J.H.; Notis, M.R.; Marder, A.R. The microstructure of 55 w/o Al-Zn-Si (Galvalume) hot dip coatings. J. Mater. Eng. 1987, 9, 133-140. [CrossRef]

37. Li, Y.; Wang, H.; Hou, B.; Feng, F.; Wei, X. Chromate passivation of hot dipped Zn25Al alloy coatings. Br. Corros. J. 2001, 36, 56-58. [CrossRef]

38. ISO 12085: 1996 Geometrical Product Specification (GPS)-Surface Texture: Profile Method-Motif Parameters; International Organization for Standardization: Geneva, Switzerland, 1996.

39. ASTM D4541-02 Standard Test Method for Pull-off Strength of Coatings Using Portable Adhesion Testers; ASTM International: West Conshohocken, PA, USA, 2002.

40. Campestrini, P.; van Westing, E.P.M.; de Wit, J.H.W. Influence of surface preparation on performance of chromate conversion coatings on Alclad 2024 aluminium alloy Part I: Nucleation and growth. Electrochim. Acta 2001, 46, 2553-2571. [CrossRef]

41. Cerezo, J.; Vandendael, I.; Posner, R.; de Wit, J.H.W.; Mol, J.M.C.; Terryn, H. The effect of surface pre-conditioning treatments on the local composition of Zr-based conversion coatings formed on aluminium alloys. Appl. Surf. Sci. 2016, 366, 339-347. [CrossRef] 
42. Qi, J.; Němcová, A.; Walton, J.R.; Zhou, X.; Skeldon, P.; Thompson, G.E. Influence of pre- and post-treatments on formation of a trivalent chromium conversion coating on AA2024 alloy. Thin Solid Films 2016, 616, 270-278. [CrossRef]

43. Treverton, J.A.; Amor, M.P. High-resolution SEM studies of chromate conversion coatings. J. Mater. Sci. 1988, 23, 3706-3710. [CrossRef]

44. Stern, M.; Geary, A.L. Electrochemical polarization I. A theoretical analysis of the shape of polarization curves. J. Electrochem. Soc. 1957, 104, 56-63. [CrossRef]

45. Wang, F.; Kang, W.; Jing, H. Principle, Method and Application of Corrosion Electrochemistry, 1st ed.; Chemical Industry Press: Beijing, China, 2008; p. 64.

46. Flitt, H.J.; Schweinsberg, D.P. Evaluation of corrosion rate from polarisation curves not exhibiting a Tafel region. Corros. Sci. 2005, 47, 3034-3052. [CrossRef]

47. Liu, W.; Li, M.-C.; Luo, Q.; Fan, H.-Q.; Zhang, J.-Y.; Lu, H.-S.; Chou, K.-C.; Wang, X.-L.; Li, Q. Influence of alloyed magnesium on the microstructure and long-term corrosion behavior of hot-dip Al-Zn-Si coating in $\mathrm{NaCl}$ solution. Corros. Sci. 2016, 104, 217-226. [CrossRef]

48. Qi, J.; Hashimoto, T.; Walton, J.; Zhou, X.; Skeldon, P.; Thompson, G.E. Formation of a trivalent chromium conversion coating on AA2024-T351 Alloy. J. Electrochem. Soc. 2016, 163, C25-C35. [CrossRef]

49. Li, L.; Swain, G.P.; Howell, A.; Woodbury, D.; Swain, G.M. The formation, structure, electrochemical properties and stability of trivalent chrome process (TCP) coatings on AA2024. J. Electrochem. Soc. 2011, 158, C274-C283. [CrossRef]

50. Sinha, S.; Badrinarayanan, S.; Sinha, A. Interaction of oxygen with $\mathrm{Zr}_{76} \mathrm{Fe}_{24}$ metglass: An X-ray photoelectron spectroscopy study. J. Less Common Met. 1986, 125, 85-95. [CrossRef]

51. Sleigh, C.; Pijpers, A.P.; Jaspers, A.; Coussens, B.; Meier, R.J. On the determination of atomic charge via ESCA including application to organometallics. J. Electron Spectrosc. Relat. Phenom. 1996, 77, 41-57. [CrossRef]

52. Qi, J.; Gao, L.; Liu, Y.; Liu, B.; Hashimoto, T.; Wang, Z.; Thompson, G.E. Chromate formed in a trivalent chromium conversion coating on aluminum. J. Electrochem. Soc. 2017, 164, C442-C449. [CrossRef]

53. Chidambaram, D.; Clayton, C.R.; Halada, G.P. The role of hexafluorozirconate in the formation of chromate conversion coatings on aluminum alloys. Electrochim. Acta 2006, 51, 2862-2871. [CrossRef]

54. Bolt, P.H.; Ten Grotenhuis, E.; Geus, J.W.; Habraken, F.H.P.M. The interaction of thin NiO layers with single crystalline $\alpha-\mathrm{Al}_{2} \mathrm{O}_{3}$ (1120) substrates. Surf. Sci. 1995, 329, 227-240. [CrossRef]

55. McGuire, G.E.; Schweitzer, G.K.; Carlson, T.A. Core electron binding energies in some group IIIA, VB, and VIB compounds. Inorg. Chem. 1973, 12, 2450-2453. [CrossRef]

56. Lindsay, J.R.; Rose, H.J.; Swartz, W.E.; Watts, P.H.; Rayburn, K.A. X-ray photoelectron spectra of aluminum oxides: structural effects on the "chemical shift". Appl. Spectrosc. 1973, 27, 1-5. [CrossRef]

57. Dake, L.S.; Baer, D.R.; Zachara, J.M. Auger parameter measurements of zinc compounds relevant to zinc transport in the environment. Surf. Interface Anal. 1989, 14, 71-75. [CrossRef]

58. Gaarenstroom, S.W.; Winograd, N. Initial and final state effects in the ESCA spectra of cadmium and silver oxides. J. Chem. Phys. 1977, 67, 3500-3506. [CrossRef]

59. Klein, J.C.; Hercules, D.M. Surface characterization of model Urushibara catalysts. J. Catal. 1983, 82, 424-441. [CrossRef]

60. Xu, Y.; Li, H.; Shen, Y.; Liu, S.; Wang, W.; Tao, J. Improvement of adhesion performance between aluminum alloy sheet and epoxy based on anodizing technique. Int. J. Adhes. Adhes. 2016, 70, 74-80. [CrossRef]

61. Niknahad, M.; Moradian, S.; Mirabedini, S.M. The adhesion properties and corrosion performance of differently pretreated epoxy coatings on an aluminium alloy. Corros. Sci. 2010, 52, 1948-1957. [CrossRef]

62. Qi, J.; Gao, L.; Li, Y.; Wang, Z.; Thompson, G.E.; Skeldon, P. An optimized trivalent chromium conversion coating process for AA2024-T351 alloy. J. Electrochem. Soc. 2017, 164, C390-C395. [CrossRef]

63. Zhang, X.; Sloof, W.G.; Hovestad, A.; van Westing, E.P.M.; Terryn, H.; de Wit, J.H.W. Characterization of chromate conversion coatings on zinc using XPS and SKPFM. Surf. Coat. Technol. 2005, 197, 168-176. [CrossRef]

64. Kong, G.; Lingyan, L.; Lu, J.; Che, C.; Zhong, Z. Corrosion behavior of lanthanum-based conversion coating modified with citric acid on hot dip galvanized steel in aerated $1 \mathrm{M} \mathrm{NaCl}$ solution. Corros. Sci. 2011, 53, 1621-1626. [CrossRef] 
65. Chang, Y.T.; Wen, N.T.; Chen, W.K.; Ger, M.D.; Pan, G.T.; Yang, T.C.K. The effects of immersion time on morphology and electrochemical properties of the $\mathrm{Cr}$ (III)-based conversion coatings on zinc coated steel surface. Corros. Sci. 2008, 50, 3494-3499. [CrossRef]

66. Li, L.L.; Desouza, A.L.; Swain, G.M. In situ pH measurement during the formation of conversion coatings on an aluminum alloy (AA2024). Analyst 2013, 138, 4398-4402. [CrossRef]

67. Li, L.; Whitman, B.W.; Munson, C.A.; Estrada, R.; Matzdorf, C.A.; Swain, G.M. Structure and corrosion performance of a non-chromium process $(\mathrm{NCP}) \mathrm{Zr} / \mathrm{Zn}$ pretreatment conversion coating on aluminum alloys. J. Electrochem. Soc. 2016, 163, C718-C728. [CrossRef]

68. Lostak, T.; Timma, C.; Krebs, S.; Flock, J.; Schulz, S. Organosilane modified Zr-based conversion layer on Zn-Al alloy coated steel sheets. Surf. Coat. Technol. 2016, 305, 223-230. [CrossRef]

69. Taheri, P.; Lill, K.; de Wit, J.H.W.; Mol, J.M.C.; Terryn, H. Effects of zinc surface acid-based properties on formation mechanisms and interfacial bonding properties of zirconium-based conversion layers. J. Phys. Chem. C 2012, 116, 8426-8436. [CrossRef]

(C) 2019 by the authors. Licensee MDPI, Basel, Switzerland. This article is an open access article distributed under the terms and conditions of the Creative Commons Attribution (CC BY) license (http://creativecommons.org/licenses/by/4.0/). 